\title{
marife
}

dini araștırmalar dergisi

Turkish Journal of Religious Studies

cilt / volume: 18 • sayı / issue: 2 • kış / winter 2018

\section{İslam Borçlar Hukukunda Akitlere Etkisi Bakımından Takyîdî Şartlar.}

\section{Mahmut Samar}

Arș. Gör. Dr., Osmaniye Korkut Ata Üniversitesi İlahiyat Fakültesi

Temel İslam Bilimleri Bölümü İslam Hukuku Ana Bilim Dalı

mahmutsamar@hotmail.com | https://orcid.org/0000-0003-0268-9115

Geliş Tarihi / Received: 16.09.2018 • Yayına Kabul Tarihi / Accepted: 27.11.2018

Öz

İslam hukuku akitler genel teorisine göre herhangi bir akdin șartlarl, hükümleri ve neticeleri kanun koyucu veya onun koyduğu prensipler doğrultusunda hukuk düzeni tarafindan belirlenmiştir. Buna rağmen taraflar bunları değiştirmek, düzenlemek ya da yeniden belirlemek istediklerinde bunu akitle birlikte şart olarak ileri sürerler. Tarafların akitle birlikte ileri sürdükleri ve üzerinde anlaştıkları bu şartlara fikıh terminolojisinde takyîlî şartlar denir. Bu şartlar, akit için hukukun belirlemiş olduğu hüküm ve neticelerin dışında bir şeyi fazladan borçlanmak ya da borçlandırmak üzere öne sürülür. Dolayısıyla takyîd, varlık kazanmış bir akdin hükümlerinin belirlenmesi, yeniden düzenlenmesi ya da değiștirilmesi anlamına gelen muhtevayı düzenleme hürriyetinin bir parçasıldır.

Bu çalıșmada akdin muhtevasını düzenlemeye yönelik ileri sürülen takyîdî șartlar ve bu șartların akitlere etkisi ele alınacaktır. Bu anlamda makalede öncelikle şart kavramı incelenecektir. Ardından İslam hukuk doktrininde takyîdî șartlarda taraflara tanınan hürriyete ve bu hürriyetin sinırlarına temas edilecektir. Anahtar Kelimeler: Fıkıh, Șart, Akit, Takyîd, Borçlar Hukuku.

\section{Restrictive Conditions and their Impact on Contracts in Islamic Obligations Law}

According to the general theory of Islamic jurisdictions, the conditions, provisions and conclusions of any act are determined by the legal order in accordance with the law-maker or its principles. Nevertheless, when the parties wish to change, regulate or re-determine them, they argue it with the motive. These conditions, in which the parties have cooperated with and act on the tactics, are referred to as restrictive conditions in fiqh terminology. These terms are put forward to borrow or debiture anything other than the provisions and conclusions that the law has established for the contract. Thus, restrictive conditions are part of the freedom of content regulation, which means the identification, reorganization or amendment of the provisions of an accused entity.

In this study, the restrictive conditions and the effect of these conditions on the contracts will be examined. In this sense, firstly the concept of condition will be examined in the article. Then, in the doctrine of Islamic law, liberty and its boundaries, which are known to the parties on the restrictive conditions, will be contacted.

Keywords: Fiqh, Condition, Contracting, Restrictive, Obligations Law.

* Bu çalışma, 2015 yılında tamamladığımız İslam Borçlar Hukukunda Akitlerde Ca'lî Şartlar başlıklı yüksek lisans tezi esas alınarak hazırlanmıştır. 


\section{Atıf / Cite as}

Samar, Mahmut. "İslam Borçlar Hukukunda Akitlere Etkisi Bakımından Takyîdî Şartlar". Marife 18/2 (2018): 501-526. https://doi.org/10.33420/marife.460423.

\section{Giriş}

İnsan fitratı gereği toplum halinde yaşama ve diğer insanlarla belli bir ölçüde iş birliği yapma mecburiyetindedir. Çünkü her yönüyle kendi kendine yeten bir insan yoktur. Her insan farklı bir kabiliyete sahip olarak yaratılmıştır. Dolayısıyla her birey toplumun ihtiyaç duyduğu farklı bir hizmeti üretmektedir. Bu da insanın ihtiyaçları için başkalarıyla münasebette bulunmasını zorunlu kılmaktadır. ${ }^{1}$ Akitler bireyin hayatı boyunca diğerleri ile arasındaki ilişkileri ve bu ilişkilerden doğan borç ve yükümlülükleri konu edinir. Akitler, insan hayatı ile o kadar özdeștir ki tarih boyunca geliştirilmiş bütün hukuk sistemleri onlara yer vermiştir. Çünkü günlük hayatta insanın yiyecek, giyecek, ulaşım, iletişim, eğitim vb. temel ihtiyaçlarının yanı sıra, devlet ve özel sektörün istihdam, üretim ve pazarlama ile ilgili gereksinimlerin karşılanması birtakım işlemlere bağlı olup akitler vasıtasıyla icrâ edilmektedir.

Akitler, belli bir amacı gerçekleștirmek için yapılır. Bu amaç, genelde bir ihtiyacın giderilmesi, bir maslahatın sağlanması veya bir zararın ortadan kaldırılmasına yöneliktir. İslam hukukunda akitlerin vücut bulması, geçerli ve bağlayıcı olması ile hukukî neticelerinin tahakkuk etmesine dair hükümler kanun koyucu tarafından belirlenmiștir. Bir akdin sahih bir şekilde meydana gelmesi ve sonuçlarını doğurması için esas olan bu ilkelerdir. Diğer taraftan, sürekli olarak artan ve değişen ihtiyaçlara paralel şekilde insanlar yaptıkları akdin içeriğini ve hukukî neticelerini düzenleme ihtiyacı duyarlar. Bazen toplumun sosyo-ekonomik ve kültürel yapısı da akitlerin muhtevasını düzenlenmeyi, hukukî sonuçlarını yeniden belirlemeyi gerekli kılmaktadır. Bu anlamda örf ve adetlerin de çoğu zaman etkili olduğu görülmektedir.

Akitlerin temelinde insanın ihtiyaç ve maslahatları yer alır. 0 halde, kural olarak bireyin dilediği şekilde akdin türünü, konusunu ve tarafını seçmesi; muhtevasını düzenlemesi yani akitle birlikte istediği şartı ileri sürmesi onun en doğal hakkıdır. Ancak her hürriyetin olduğu yerde bir sınırlamanın, her hakkın karşılığında bir yükümlülüğün olması da göz ardı edilmemelidir. Bu nedenle diğer hukuk sistemlerinde olduğu gibi İslam borçlar hukukunda da akitlerde muhtevayı düzenleme hürriyeti ve sınırları tartışmalı bir konudur. İttifak halinde olan tek husus, bu hürriyetin mutlak olmadı̆̆ıdır.

Akdin gereğini ve hukukî neticelerini düzenlemek veya değiştirmek akitle birlikte ileri sürülen şartlar ile sağlanmaktadır. Pozitif hukukta yan edim yükümleri olarak bilinen bu şartlara ${ }^{2}$ fikhî terminolojide takyîdî şartlar denmektedir. $\mathrm{Bu}$ konu her iki hukuk sisteminde de "akit/sözleşme

\footnotetext{
Aynî, Ebû Muhammed Mahmud b. Ahmed, el-Binâye fi şerhi'l-Hidâye, thk. Eymen Salih Şâban (Beyrut: Dâru'l-Kütübi'l-ilmiyye, 2000), 10: 222.

2 Eren, Fikret, Borçlar Hukuku Genel Hükümler (Ankara: Beta yayınlarI:1987), I: 34.
} 
serbestisi/hürriyeti" ve buna bağlı olarak "şart koşma serbestisi/hürriyeti" veya "akdin muhtevasını düzenleme serbestisi/hürriyeti” kapsamında ele alınmaktadır.

İslam hukuku ilke olarak akit serbestisini ve dolayısıyla akitlerde şart koşma hürriyetini kabul eder. Nitekim ticarî hayatta karşılıklı rıza, İslam borçlar hukukunun en önemli ilkelerindendir. Akitlerde açıklık ve dürüstlüğün bulunması ile beklenmedik zararların önlenmesi de önemli ilkelerdendir. Buna göre tarafların açık iradeleriyle ortaya çıkan şartlar, ilke olarak geçerli ve tarafları bağlayıcıdır. Buna karşılık sözleşmenin dürüstlüğünü ve şeffaflığını, üçüncü şahısların hukukunu ve toplumun maslahatını koruma gayesiyle tarafların şart hürriyeti hatta akit hürriyeti gerektiğinde sınırlanabilir.

$\mathrm{Bu}$ çerçevede tarafların akitle birlikte ileri sürdükleri şartların geçerliliğini delilleriyle birlikte ele alıp illetlerini tespit etmek, doktrindeki tartışmaları ele almak, bu görüşler üzerinden bir değerlendirme yapmak; sözleşmelerde şart koşma sınırının belirlenmesine yardımcı olacaktır. $\mathrm{Bu}$ da tespit edilen sınırlar içerisinde kalan şartların geçerli, diğerlerinin ise geçersiz olmasını gerektirecektir. Dolayısıyla birey, şart koşma konusundaki tasarruflarında hukukun desteğini alıp alamayacağını bilecektir. Çünkü hukuk, meşru kabul ettiği tasarrufları neticeleriyle birlikte kabul etmek ve korumakla mükelleftir.

\section{Sart Kavramı}

Şart, Arapça bir kelime olup sözlükte "koşul", "kayıt", "sınırlama" "hal", "durum", "bir şeyin gerçekleşmesi için gerekli olan şey" gibi manalara gelmektedir. ${ }^{3}$ Fıkıh terminolojisinde ise şart, hukukî bir işlemin meydana gelmesi, işlerlik kazanması, hükümlerini doğurması veya bunların sona ermesinin, gelecekte gerçekleşmesi muhtemel bir olaya bağlanması ya da hukukî bir işlem için kayıtlar konmasını ifade eden bir kavramdır.4 Türk borçlar hukukunda şart kavramının, geniş ve dar olmak üzere iki anlamı vardır. Geniş manada şart, bir hukukî sözleşmede tarafların istedikleri şekilde koydukları hükümlerdir. Dar anlamda ise, bir sözleşmenin varlığının veya hukukî neticelerinin, gerçekleşmesi kesin olmayan gelecekteki bir olaya bağlanmasını ifade eder. ${ }^{5}$

Şart kavramının tanımı dikkate alındığında hukukî işlemlerde şarttan söz edebilmek için birtakım unsurların bulunması gerekir. Buna göre şart, işlemin aslından olmayan tamamlayıcı (ârızî) bir niteliktedir. Akitten doğan borçlanmanın

3 İbn Manzûr, Muhammed b. Mükerrem (ö. 711/1311), Lisânü'l-'Arab (Beyrut: Dâr Sadr, 1993), 7: 329; Feyyûmî, Ahmed b. Muhammed b. Ali (ö. 770/1368), el-Misbâhu'l-münîr fi garibi'ş-șerhi'l-kebîr (Kahire: Dâru'l-Hadîs, 2003), 2: 309.

4 Serahsî, Şemsu'l-eimme Muhammed b. Ahmed b. Sehl, el-Mebsût (Beyrut: Dâru'l-Ma'rife, 1989), 2: 303; Debûsî, Ebû Zeyd Ubeydullah Ömer b. İsa, Takvîmu'l-edille fi usûli'l-fikh, thk. Halil el-Meys (Beyrut: Dârü'l-Kütübi'l-ilmiyye, 2001), 384; Abdülkerîm Zeydân, el-Medhal lidirâseti'ş-Şeriati'lÍslamiyye (Beyrut: Müessesetü'r-Risâle, 2002), 46-47 Zerkâ, Mustafa Ahmed, el-Medhalü'l-fikhiyyü'l'âm (Dimeşk: Dâru'l-Kalem, 1998), I:392; Şâtıbî, Ebû İshak İbrahim b. Musa, el-Muvâfakât, trc. Mehmet Erdoğan (İstanbul: İz yayıncılık, 2010), I: 261; Şâzelî, Hasan AlI: Nazariyyetu'ş-şart fi'l-Fıkhi'lİslamî, Dirâse mukârene beyne'l-fikhi'l-İslâmi ve'l-kânûn (Kahire: y.y., ty.), 9; Boynukalın, Mehmet, "Şart", Türkiye Diyanet Vakfi Íslam AnsiklopedisI: (Ankara: TDV YayınlarI: 2010), 38: 364.

5 Recep Çiğdem, Mukayeseli Borçlar Hukuku (İstanbul: Rağbet YayınlarI: 2012),196. 
kendisine bağlı olduğu, ileride gerçekleșmesi muhtemel ve mümkün bir durumdur. 6

Şunu belirtmek gerekir ki şart kavramı öncelikle şer'î (kânûnî) ve ca'lî (irâdî) olmak üzere ikiye ayrılmaktadır.7 Kaynağı kanun koyucu (Şârî') olan şartlara şer'î şart denir. Hakiki şart olarak da anılan bu şartları, bir şeyin gerçekleşmesi için kanun koyucunun gerekli kıldığı şartlar olarak ifade etmek de mümkündür. ${ }^{8}$ Akitler açısından söylemek gerekirse; akdin varlık kazanması (in'ikâd), ${ }^{9}$ yürürlüğe girmesi (nefâz), ${ }^{10}$ bağlayıcı olması (lüzum) ${ }^{11}$ ve sıhhat kazanması için aranan şartlar ${ }^{12}$, kanunî (șer'î) şartlardır.

Kaynağı mükellefin iradesi olan ve tarafların akitle beraber ileri sürdükleri ve üzerinde anlaştıkları şartlara ca'lî (irâdî) şartlar denmektedir. ${ }^{13}$ Bu şartlara, akdî şartlar veya akde mukarin (bitişik) şartlar da denir. ${ }^{14} \mathrm{Bu}$ şartlara ca'lî veya akdî şart denmesinin sebebi; taraflardan birinin onu akitle birlikte şart kılması yani şart olarak ileri sürmesidir. ${ }^{15}$ Akitle birlikte tarafların iradeleriyle ortaya çıkan ve akdin hukuken vücut bulmasını, işleyişini, hüküm ve sonuçlarını belirleyen üç tür ca'lî/akdî şart vardır. Bunlardan biri, varlık kazandıktan sonra bir akitten doğan hak ve borçları düzenleyen, sınırlayan veya değiştiren şartlardır ki bunlara takyîdî şartlar denmektedir. Satın alınan bir ev eşyasının eve teslim edilmesini şart koşmak böyledir. ${ }^{16}$ Diğer ikisi ise hukukî bir işlemin kurulması kendisine bağlı bulunan şartlar şeklinde tarif edilen ta'lîkî şart $^{17}$ ve hükümlerinin işlemeye başlamasının ve geçerliliğinin gelecekteki bir zamana bağlanması anlamına gelen izâfî şarttır. ${ }^{18}$ Buna göre bir evin kiraya verilmesi için "okulu bitirme” şartını

6 Cüveynî, Ebû'l-Meâlî Abdülmelik b. Abdillah, Kitâbü't-Telhîs fî usûli'l-fikh, thk. Abdullah Cevlim enNiybâli-Beşîr Ahmed el-Ömerî (Beyrut: Dâru'l-Beşâiri'l-İslâmiyye, 1996), 2: 92; Şâzelî, Nazariyyetu'şşart, 9-15; Turgut Akıntürk, “Şart ve Mükellefiyet Kavramları Üzerine Bir İnceleme”, Ankara Üniversitesi Hukuk Fakültesi Dergisi 27/3 (Eylül1970): 224.

7 Zerkâ, el-Medhal, I: 394.

8 Zerkâ, el-Medhal, I: 393-394; Vehbe ez-ZuhaylI: el-Flkhu'l-İslamî ve edilletüh (Dımeşk: Dâru'l-Fikr, 1989), 4: 580; Boynukalın, “Şart”, 28: 364; Recep Özdirek, İslam Hukukunda Akdin Sınırları (İstanbul: Yedirenk yayınlarI: 2010),139.

9 Serahsî, el-Usul, 2: 321; Orhan Çeker, İslam Hukukunda Akidler (Konya: Tekin kitabe6: 2010), 72.

${ }^{10}$ Feyyûmî, el-Misbâh, 366; Boynukalın, "Şart", 28: 364; Mehmet Erdoğan, Flkıh ve Hukuk Terimleri Sözlüğü (İstanbul: Ensar yayınları, 2010), 450.

${ }^{11}$ Çeker, İslam Hukukunda Akidler, 104.

12 Mevsılî, Ebü'l-Fazl Mecdüddin Abdullah b. Mahmûd b. Mevdûd, el-Ihtiyar li-ta'lili'l-Muhtar, thk. Muhammed Adnan Derviş (Beyrut: Dâru'l-Kütübi'l-ilmiyye, 1997), 2: 273; Çeker, İslam Hukukunda Akidler, 97.

${ }^{13}$ Abdülkerim Zeydân, el-Vecîz fî usuli'l-fikh (Beyrut: Müessesetü'r-Risâle, 2012), 48.

${ }^{14}$ Merğînânî, Burhanuddîn Ebû'l-Hasen Ali b. Ebû Bekir, el-Hidaye fí șerhi Bidayeti'l-mübtedî, thk. Tallâl Yusuf (Beyrut: Dâr İhyai't-türâsi'l-'Arabî, 2004), 3: 48; Muhammed Fethi ed-Düreynî, Buhûs mukârene fi'l-fikhi'l-İslamî (Beyrut: Müessesetü'r-Risâle, 2008), 2: 372; Orhan Çeker, Fıkıh Dersleri I: (Konya: Ensar yayıncılık, 2011), 60.

15 Zekiyuddîn Şa'bân, İslam Hukuk İlminin Esaslarl: trc. İbrahim Kâfi Dönmez (Ankara: TDV YayınlarI: 2010), 267.

${ }^{16}$ Merğînânî, el-Hidâye, 3: 50.

17 İbn Nüceym, el-Eşbah ve'n-nezâir 'alâ mezhebi Ebî Hanîfe en-Nu'mân, thk. Zekeriya Umeyrât (Beyrut: Dâru'l-kütübi'l-İlmiyye, 2010), 211; Zeydân, el-Vecîz, 48; Düreynî, Buhûs, 2: 373; Karaman, Ana Hatlarıyla Íslam Hukuku (İstanbul: Ensar neşriyat, 2014), 3: 89.

18 Serahsî, el-Mebsût, 26: 21; Düreynî, Buhûs, 2: 373. 
koşmak ta'lîk, kira akdinin yapılıp kira süresinin "iki ay sonra başlamasını" şart koșmak izâfettir.

Biz burada yalnızca takyîdî şartlar ve bu şartların akitlere etkisi üzerinde duracağız. Zaten İslam borçlar hukukunda ca'lî şartlardan üzerinde en çok durulan ve tartışılan şartlar da bu tür şartlardır. Hatta literatürde çoğu zaman "akdî şartlar", "akde mukârin (bitişik) şartlar" veya "fâsit şartlar" dendiğinde takyîdî şartlar kastedilir. Nitekim Zerkâ'nın (ö. 1999) "sözlü tasarrufların gerektirmediği bir yükümlülüğü ek şartlarla gerekli kılma"19 şeklindeki akdî şart tarifi ile Karadağ̂̂’nin "mutlak sözleşmenin gerektirmediği bir borçlanmayı gerekli kılmaktır"20 şeklindeki tanımı bu şekildedir.

\section{Takyîdî Şart Kavramı ve Mahiyeti}

Takyîdin kelime anlamı; sınırlama, kayıt koyma, belirleme, tayin etme, dahil etme, kaydetme ve bağlama olarak karşımıza çıkmaktadır. Sözlük anlamından hareketle takyîd, bir șeyin olmayan sınırlarını belirlemek șeklinde olduğu gibi var olan sınırlarını daraltmak veya genişletmek olarak da anlaşılabilir. ${ }^{21}$ Fıkhî istılahta ise takyîdî șart, "tarafların, akdin gerektirdiği hükümleri ve neticeleri belirlemek, değiştirmek veya düzenlemek amacıyla akitle birlikte ileri sürdükleri şartlar" şeklinde tanımlanmaktadır. ${ }^{22}$ Satıcının evini içinde bir müddet oturma şartıyla satması, takması şartıyla camcıdan cam alınması, eve teslim etmesi şartıyla mobilya alınması, rehin veya kefil istenmesi vb. şekilde gerçekleşen akitlerin hepsinde öne sürülen şartlar bu türdendir.

Takyîdî şart, akdin hukuken gerçekleşmesini ve hükümlerini derhal doğurmasını etkilemez. Bu yönüyle izâfî ve ta'lîkî şartlardan ayrılır. Çünkü böyle bir şarta bağlı olarak gerçekleşen akit, karşılıklı ve birbirine uygun irade beyanıyla hukuken varlık kazanmış, hükümlerini derhal doğurmuş olur. Tarafların ileri sürdüğü şart ise akdin hükümlerini belirleme/düzenleme amacıyla sınırlayıcı mahiyettedir. Kısaca takyîdî şart, sözleşmenin varlık veya işlerlik kazanmasına değil netice ve hükümlerine etki eder. ${ }^{23}$

Takyîdî şartlar, tasarrufun aslî gereklerinden değildir. Nitekim hukukî işlemlerden doğan borç ve yükümlülükler kanun koyucu tarafından belirlenmiştir. Hukukun belirlediği hüküm ve neticelerin dışında bir şeyi şart koşmak hukukun gerektirmediği fazladan bir iş olur. Mesela, satım akdinde satıcı müşteriden kefil veya rehin ister, müșteri de bunu kabul ederse, rehin veya kefil satım akdinin gereği olmayan fazladan borçlandırmalardır. Çünkü mutlak satım akdinin vücut bulması bu şarta bağlı değildir. Zira bunlar olmadan da satım akdi sahih bir şekilde

19 Zerkâ, el-Medhal, I: 571.

${ }^{20}$ Ali Muhyiddîn el-Karadâğî, Mebde'ü'r-rızâ fi'l-'ukûd: Dirâse mukârene fi'l-fikhî'l-İslamî (Beyrut: Dâru'lBeşâir, 1985), 2: 1154.

${ }^{21}$ İbn Manzûr, Lisânu'l-'Arab, 3: 370; Firuzâbâdî, Mecduddîn Muhammed b. Yakub, el-Kâmusu'l-muhît, thk. Muhammed Naim el-'Arğûsî danıșmanlığında yayınevi (Beyrut: Müessesetü'r-Risâle, 2005), 401.

${ }^{22}$ Zerkâ, el-Medhal, I: 572; Zeydân, el-Vecîz, 48; Düreynî, Buhûs, 2: 372; Karaman, Ana Hatlarıyla İslam Hukuku, 3: 99.

${ }^{23}$ Zerkâ, el-Medhal, I: 578. 
yapılabilir. $^{24}$ Dolayısıyla takyîdî şarttan doğan borçlar, hukuki işlemin esaslı unsurlarından değildir. Nitekim modern hukukta bu borçlara yan edim denmektedir. ${ }^{25}$

Akitlerde takyîdî şarttan söz edebilmek için şartın, akdin kurulması anında icap ve kabulle birlikte ileri sürülmesi gerekir. Akit kurulmadan önce ileri sürülen şart bir borçlanmayı içeriyorsa bile takyîdî şart olarak nitelenmez. Akdin hukuken kurulmasından ve bağlayıcı hale gelmesinden sonra ileri sürülen şartlar ise boş söz (lağv) hükmünde olup, hiçbir sonuç doğurmaz. ${ }^{26}$

\section{Akitlere Etkisi Bakımından Takyîdî Şartlar} kısımdır:

Akitlere etkisi bakımından takyîdî şartlar sahih, fasit ve batıl olmak üzere üç

\subsection{Sahih Şartlar}

Klasik fikıh doktrininde akitle birlikte şart koşulduğunda akdin hükmünü etkilemeyen takyîdî şartlar sahih olarak nitelenmektedir. Klasik kaynaklarda dağınık şekilde bulunan bu şartları beş başlık altında toplamak mümkündür:

\subsubsection{Akdin Gereği (Muktezâsı) Olan Şartlar}

Fıkıh terminolojisinde "akdin muktezâsı", bir akdin kural olarak gerektirdiği hukukî sonuçlar ve taraflara yüklediği hak ve sorumluluklar olarak tarif edilmektedir. ${ }^{27}$ Fıkıh bilginleri, her bir akdin taraflara ne gibi borçlar yüklediğini şer'î naslara ve fıkhın genel prensiplerine dayanarak ayrı ayrı tespit etmişlerdir. Mesela satıcının, akit konusu malı müşteriye teslim etmesi, bu maldaki ayıptan sorumlu olması, müşterinin parayı ödemesi, satım akdinin gereği/muktezâsı olan borçlardır. ${ }^{28}$

Bu şartları bizzat akdin sonucu olarak görmek mümkündür. Örneğin semeni alana kadar akde konu olan malı müșteriye teslim etmemeyi şart koşmak geçerlidir. Bu vb. şartların sahih olduğu açıktır. Bilakis bunları ortadan kaldıran, daraltan veya arttıran şartların koşulması geçerli değildir. Çünkü akit, bizzat bu şartların yerine getirilmesi için yapılır. Bu konuda İslam hukukçularının tamamı aynı görüştedir. ${ }^{29}$ Esasen akdin gereği olan bu tür şartlara, şart denmesi mecâzî

${ }^{24}$ Düreynî, Buhûs, 2: 372 .

${ }_{25}$ Ahmet Mehmet Kılıçoğlu, Borçlar Hukuku Genel Hükümler (Ankara: Turhankitabe6: 2009), 20.

${ }^{26}$ İbn Hazm, Ebu Muhammed Ali b. Ahmet b. Said, el-Muhallâ bi'l-âsâr, thk. Abdülğaffâr Süleyman elBindârî (Beyrut: Dâru'l-Kütübi'l-İlmiyye, 1934), 9: 412; Düreynî, Buhûs, 2: 372.

${ }^{27}$ Düreynî, Buhûs, 2: 371 .

${ }^{28}$ Senhûrî, Abdurrezzâk Ahmed, Mesâdiru'l-hak fi'l-fikhî'l-İslamî (Beyrut: Menșûrâtü'l-Halebî, 1998), 3: 107; Zeydân, el-Medhal, 332; Karadâğî, Mebdeu'r-rizâ, 2: 1140-1141; Ali Bardakoğlu, "İslâm Hukukunda Akit Hürriyeti ve Akdî Şartlar Açısından Bu Hürriyetin Sınırı”, Erciyes Üniversitesi Illahiyat Fakültesi Dergisi 1 (Bahar 1983), 16-17

${ }^{29}$ KâsânI: Ebû Bekr Alâuddîn b. Mes'ûd, Bedai'u's-sanâi' fi tertibi'ş-şerâi', thk. Ali Muhammed Muavviz ve Âdil Ahmed Abdülmevcûd (Beyrut: Dâru'l-Kütübi'l-İlmiyye, 2003), 7: 15; Merğînânî, el-Hidâye, 3: 48; Burhânü'ş-Şerîa, Burhânüddîn Mahmud b. Ahmed b. Abdulazîz el-Buhârî, el-Muhîtu'l-Burhânî fi'l fikhî'n-Nu'mânî, thk. Abdulkerîm Sâmi el-Cündî (Beyrut: Dâru'l-Kütübi'l-İlmiyye, 2004), 6: 389; 
olup hakîkî değildir. Zira akdin gereği olan bir hususun şart olarak ileri sürülmesine gerek yoktur. Ancak akdin gereğini kuvvetlendirmek için ileri sürülmektedir. Hatta delil olmadığı sürece, akit yapan tarafların bizzat akdin gereği olan sonuçlara aykırı, onları kayıtlayıcı, azaltıcı veya arttırıcı bir şart ileri sürmeleri sahih değildir. ${ }^{30}$

\subsubsection{Akdin Amacına Uygun Olan Şartlar}

Bu şartların kapsamı konusunda fıkıh mezheplerinin yaklaşımları farklıdır. Hanefî ve Şafiî mezheplerine göre sadece akitten doğan sonuçları güvence altına alarak yerine getirilmesini kuvvetlendiren şartlar akdin amacına uygundur. Mâlikî ve Hanbelîler ise, akdin gereğine aykırı olmayan şartların hepsini bu kapsamda değerlendirirler. Buna göre, müşteriden kefil istenmesi, rehin bırakması veya borcu havâle etmesi yönündeki şartlar ittifakla sahihtir. ${ }^{31}$

Hanefiler, bu şartların sıhhatini istihsan ile temellendirirler. Çünkü mezhepte genel kurala göre akdin gereğinden olmayan her şart fasittir. Kefil, rehin vb. bir şartın koşulması bizzat akdin gereği değildir. Ancak bu şartların ileri sürülmesine ihtiyaç vardır. Zira akdin neticeleri bu vb. şartlarla güvence altına alınmaktadır. Ayrıca bu şartlar taraflar arası anlaşmazlığa yol açmaz. Bu nedenle

Kummî, İbn Bâbeveyh, Ebû Ca'fer Muhammed b. Ali b. Hüseyn, Kitâb Men la yahduruhu'l-fakîh, thk. Hüsein el-A'lemî (Beyrut: y.y., 1986), 3: 130-131; Nevevî, Ebû Zekeriyya Yahya b. Şerif b. Mürî, elMecmû' șerhu'l-Mühezzeb (Beyrut: Dâru'l-fikr, ty.), 9: 447; İbnü'l-Hümâm, Kemâlüddîn Muhammed b. Abdilvâhid b. Abdilhamîd es-Sivâsî el-İskenderî, Fethu'l-Kadîr, thk. Abdürrezzâk Galib el-Mehdî (Beyrut: Dâru'l-Kütübi'l-İlmiyye, 2003), 6: 404; İbn Nüceym, Zeynulâbidîn b. İbrahim, b. Muhammed, el-Bahru'r-râik şerhu Kenzu'd-dekâik, thk. Zekeriya 'Umeyrât (Beyrut: Dâru'l-Kütübi'l-ilmiyye, 1997), 6: 140; Buhûtî, Mansûr b. Yunus b. İdris, Keșşâfu'l-kına' an metni'l-İkna', thk. Muhammed Emîn ezZinnâvî (Beyrut: Âlemü'l-kütüb, 1997), 2: 494; İbn Âbidîn, Muhammed Emin b. Ömer b. Abdilaziz edDımaşkî, Reddü'l-muhtâr 'ale'd-Dürri'l-muhtâr şerhu Tenviri'l-ebsâr, thk. Adil Ahmed Abdülmevcûd Ali Muhammed Muavviz (Riyad: Dâr 'Alemü'l-kütüb, 2003), 7: 284; San'ânî, Ahmed b. Kasım el-İnsî el-Yemenî, et-Tâcu'l-müzehheb li ahkâmi'il-mezheb, șerhu metni'l-Ezhâr fi fikhî'l-eimmeti'l-ethâr (San'â: Dâru'l-Hikmeti'l-Yemâniyye, 1993), 2: 370; Ömer Nasuhi Bilmen, Hukuki İslâmiyye ve Istalahat-ı Flkhîyye Kâmusu (İstanbul: Sarmaşık, 1970), 6: 23; Senhûrî, Mesâdiru'l-hak, 3: 107; Şâzelî, Nazariyyetu'ş-şart, 173; Çeker, Fıkıh DerslerI: 64.

${ }^{30}$ İbn Kudâme, Ebu Muhammed Ali b. Ahmed b. Muhammed, el-Muğnîthk. Abdullah b. Abdülmuhsin etTurkî-Abdülfettah Muhammed (Riyad: Dâr 'Âlemi'l-kütüb, 1997), 6: 323; Suyûtî, Celâlüddîn Abdurrahman, el-Eşbâh ven-nazâir fi kavâidi ve fürûi fikhî’ş-Şâfiiyye (Riyad: y.y., 1997), I: 245; Senhûrî, Mesâdiru'l-hak, 3: 103, 108; Zeydân, el-Medhal, 332; Düreynî, Buhûs, 2: 374; Karadâğî, Mebdeü'r-rizâ, 2: 1167.

${ }^{31}$ Serahsî, el-Mebsût, 13: 18; Kâsânî, Bedâi'u's-sanâi', 7: 15; İbn Kudâme, el-Muğnî, 6: 322-323; İbn Receb el-Hanbelî, Ebü'l-Ferec Zeynüddîn Abdurrahmân b. Ahmed b. Abdirrahmân Receb el-Bağdâdî edDımaşkî, el-Kavâid (Taksrîrü'l-kgavâ'id ve tahrîrü'l-fevâ'id) (Beyrut: Dâru'l-Kütübi'l-ilmiyye, ty.), I: 451; Buhûtî, Keşşâfu'l-kına', 2: 495; Burhânüddîn el-Buhârî, el-Muhitu'l-Burhânî, 6: 389; Karâfî, Ebü'lAbbâs Şihâbüddîn Ahmed b. İdrîs b. Abdirrahmân el-Misrî, Envârü'l-burûk fî envâ'i'l-furûk; el-Furûk, thk. Ömer Hasan el-Kayyâm (Beyrut: el-Mektebetü'l-Asriyye, 2014), I: 397; Şâtıbî, el-Muvâfakât, I: 281-283; İbn Nüceym, el-Bahru'r-râik, 6: 140; Muhammed b. Hatîb eş-Şirbînî, Muğni'l-muhtâc ila ma'rifeti me'âni'l-Minhâc, thk. Muhammed Halil 'Aytânî (Beyrut: Dâru'l-Ma'rife, 2014), 2: 43; Remlî, Ebû Abdillâh Şemsüddîn Muhammed b. Ahmed b. Ahmed b. Hamza er-Remlî el-Menûfî el-Ensârî elMısrî, Nihâyetü'l-muhtâc ilâ şerhi'l-Minhâc (Beyrut: Dâru'l-Kütübi'l-ilmiyye, 2003), 3: 452; Kummî, Men la yahduruhu'l-fakîh, 3: 130-131; San'ânî, et-Tâcu'l-müzehheb, 2: 370; Hâşim Ma'rûf, el-Huseynî, Nazariyyetü'l-akd fi'l-fikhîll-Câferî (Beyrut: Dâru't-te'ârif, 1996), 442; Bilmen, Hukuk-ı İslamiyye ve Istılâhât-ı Fıkhiyye Kâmusu, 6: 23; Şâzelî, Nazariyyetu'ş-șart, 179, 217; ZuhaylI: el-Fıkhu'l-İslamî, 4: 477; Senhûrî, Mesâdiru'l-hak, 3: 112. 
akdin muktezasını kuvvetlendiren şartlar, ihtiyaç halinde maslahata binaen yerleşik kuraldan istisna edilebilir. ${ }^{32}$

Mâlikîler'e göre, bu şartlar akdin yapılış gayesini gerçekleştirmeye yöneliktir. Dolayısıyla akdin gereği değilse de buna aykırı değildir. Ayrıca akdin veya taraflardan birinin maslahatını gerçekleştirmeye yönelik şartlardandır. $\mathrm{Bu}$ nedenle bu şartların hepsi geçerli ve bağlayıcıdır. ${ }^{33}$ Şâfiî ve Hanbelîler'in de yaklaşımları buna yakındır. ${ }^{34}$

Böyle bir şartla yapılan akitler, hukuken varlık kazanır ama yürürlüğe girmez. Farklı bir tabirle akit, şartın (rehin, kefil vb.) yerine getirilmesine bağlı mevkuftur. Bu şartlar sahih olduğu için tarafları bağlayıcıdır. Yerine getirilmediği vakit şartı koşan taraf akdi bozma ve akde onay (icâzet) verme konusunda muhayyerdir. Mesela, rehin veya kefil şartıyla yapılan bir satım akdinde müşteri bu şartı yerine getirmezse satıcı onu bu şartı yerine getirmesi için zorlayamaz. Dilerse akdi fesheder, dilerse olduğu haliyle onay verir. Çünkü satıcı, malının rehin almadan mülkünden çıkmasına razı değildir. Akitlerde ise karşılıklı rıza esastır. Ancak müşteri, rehinin kıymetini veya semeni ödemekle akdin işlerlik kazanmasını sağlayabilir. ${ }^{35}$

$\mathrm{Bu}$ şartların "Peygamberimiz şartlı satışları yasaklamıştır."36 hadisine rağmen geçerli kabul edilmesini, İslam hukukçuları şu şekilde izah ederler: Hanefîler'e göre, bunlara şart denmesi ismen olup, hakikat itibariyle değildir. $\mathrm{Bu}$ nedenle hadisteki yasağın kapsamına dahil değildir. Ayrıca bu rivayetten anlaşılan genel hüküm sünnet, örf, maslahat gibi başka delillerle tahsis edilmiştir. ${ }^{37}$ Mâlikîler hadiste yasaklanan şartı, akdin gereğiyle çelişen şartlar olarak anladıkları için, bunları geçerli kabul ederler. ${ }^{38}$ Şâfiî hukukçular, bu hadisin başka delillerle (Bakara, 2/229; Mâide, 5/3) tahsis edildiğini savunurlar. Ayrıca yasaklanan şart,

32 Şeybânî, Muhammed b. Hasan, el-Asl (el-Mebsût), thk. Mehmet Boynukalın (Beyrut: Dâr İbn Hazm, 2012), 2: 442; Serahsî, el-Mebsût, 13: 18; Kâsânî, Bedâi'u's-sanâi', 7: 16; ZuhaylI: el-Flkhu'l-İslamî, 4: 478.

33 Senhûrî, Mesâdiru'l-hak, 3: 113; Şâzelî, Nazariyyetu'ş-şart, 215; Vehbe ez-Zuhaylî, el-Fikhu'lMâlikiyyu'l-müyesser (Dımașk: Dâru'l-Kelimi't-Tayyib, 2010), I: 396; Karadâĝ̣̂, Mebdeü'r-rizâ, 2: 1173.

${ }^{34}$ Şîrâzî, Ebu İshak İbrahim b. Ali b. Yusuf, el-Mühezzeb fî fikhîl'-imam eş-Şâfiî, thk. Zekeriyya Umeyrât (Beyrut: Dâru'l-Kütübi'l-ilmiyye, 1995), 2: 22; Buhûtî, Keş̧ŝffu'l-kına', 2: 497; İbn Teymiyye, Takiyuddin Ahmed b. Abdulhalim, el-Fetâve'l-Kübrâ, thk. Muhammed Abdulkadir Atâ - Mustafa Abdulkadir Atâ (Beyrut: Dâru'l-Kütübi'l-ilmiyye, 1987), 6: 81; İbn Receb, el-Kavâid, I: 231-233; Senhûrî, Mesâdiru'l-hak, 3: 113; Şâzelî, Nazariyyetu'ş-şart, 215.

${ }^{35}$ Sahnûn, Ebû Saîd Abdisselam b. Saîd et-Tenûhî, el-Müdevvenetü'l-kübrâ (Beyrut: Dâru'l-Kütübi'lİlmiyye, 1994), 3: 202; Serahsî, el-Mebsût, 13: 19; Kâsânî, Bedâi'u's-sanâi', 7: 16; Burhânüddîn elBuhârî, el-Muhitu'l-Burhânî, 6: 390; Nevevî, el-Mecmu', 9: 447; Șirbînî, Muğni'l-muhtâc, 2: 43-44; İbn Nüceym, el-Bahru'r-râik, 6: 140; Remlî, Nihâyetü'l-muhtâc, 3: 455; San'ânî, et-Tâcu'l-müzehheb, 2: 374; Bilmen, Hukuk-ı İslamiyye ve Istılâhât-ı Fıkhiyye Kâmusu, 6: 23.

36 Taberânî, Ebû'l-Kasım Süleyman b. Ahmed b. Eyyub b. Mutayr el-Lahmî, el-Mu'cemü'l-evsat, thk. Tarık b. İvazullah b. Muhammed - Abdülmuhsin b. İbrahim el-Huseynî (Kahire: Dâru'l-Harameyn, ty.), 4: 335 (4361).

${ }^{37}$ Kâsânî, Bedâi'u's-sanâi', 7: 24.

38 İbn Rüşd el-Cedd, Ebû'l-Velîd Muhammed b. Ahmed, el-Beyân ve't-tahsîl ve'ş-șerh ve't-tevcîh ve't-ta'lîl li-mesâili'l-müstahrece, thk. Muhammed Huccî (Beyrut: Dâru'l-Ğarbi'l-İslâmî, 1988), 7: 267, 330; İbn Rüşd el-Hafîd, Ebu'l-Velîd Muhammed b. Ahmed, Bidayetü'l-müçtehit ve nihâyetü'l-muktesıd, thk. Ferîd Abdülaziz el-Cündî (Kahire: Dârü’l-Hadîs, 2004), 3: 1640. 
taraflar arası anlaşmazlığa yol açmakla mukayyettir. $\mathrm{Bu}$ şartlar ise akdin maslahatını gerçekleştirmek ve hükümlerini kuvvetlendirmek suretiyle çekişmeye yol açmaz. Tam aksine, anlaşmazlığı ortadan kaldırır. ${ }^{39}$ Ca'ferî ve Hanbelî hukukçular ise bu rivayeti sahih kabul etmezler. ${ }^{40}$

\subsubsection{Kanun Koyucunun İzin Verdiği Şartlar}

Kanunun izin verdiği şartlarla, akdin gereği olmayan ve genel kıyasa aykırı olmakla birlikte sıhhati hakkında nas olan şartlar kastedilir. ${ }^{41}$ Zira akdin gereği olan bir şeyin şart koşulması için, onunla ilgili özel hüküm bildiren bir nassa ihtiyaç yoktur. Yukarıda ifade edildiği üzere bunlar bizzat akit yapmanın gayesidir. 0 halde hukukun belirlediği şekilde kurulan her akit, neticelerini ve hükümlerini doğurur. ${ }^{42}$

İslam hukukçularının tamamı hukukun izin verdiği şartları sahih kabul ederler. Zaten bunun böyle olması da açıktır. Şart muhayyerliği ve vade şartıyla yapılan satım akdi bunun en tipik örnekleridir. 43 "...Belirlenmiş bir vakte kadar

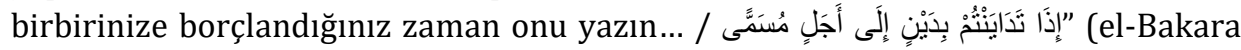
2/282) ayeti vade şartının, alışverişlerinde sürekli aldanan Hibban b. Münkîz (r.a) için Hz. Peygamber (s.a.s): "Alışveriş yaptığın zaman "aldatma yok, benim için üç gün muhayyerlik vardır" de"44 rivayeti de muhayyerlik şartının geçerliliğine delalet eder.

Hanefî mezhebinde akdin gereği olmayan şartların, kıyasa aykırı olduğunu belirtmiştik. Bedeli daha sonra ödenmek üzere yapılan satım akdi de onlara göre böyledir. Çünkü akdin gereği, müşterinin akit konusu mala, satıcının da bedeline derhal sahip olmasıdır. Ancak bu konuda müdâyene ayeti (el-Bakara 2/282), ${ }^{45}$ özel bir hüküm bildirmiştir. Bu nedenle Hanefîler, vadeli alışveriş yapmayı kıyasa muhalif olarak istihsân ile temellendirirler. ${ }^{46}$

Hanefî mezhebinde şart muhayyerliği konusunda da aynı durum söz konusudur. ${ }^{47}$ Burada muhayyer olma şartının kıyasa muhalif olduğunu savunurlar. Çünkü bu konuda kıyas, "Hz. Peygamber (s.a.s) gararlı satışı yasakladı"48 rivayetinin genel hükmüdür. $\mathrm{Bu}$ şart ise akdin varlık kazanmasında bir belirsizliğe muhayyerlik hakkının düşüp düşmemesi- yol açmaktadır. Ancak Hibbân (r.a) hadisi, kıyasa muhalif olarak konuyla ilgili özel bir hüküm bildirmiștir. ${ }^{49}$ Diğer

\footnotetext{
${ }^{39}$ Şâzelî, Nazariyyetu'ş-şart, 253-254.

${ }^{40}$ Buhûtî, Keşşâfu'l-kına', 2: 497; İbn Teymiyye, el-Fetâve'l-Kübrâ, 4: 80; Şâzelî, Nazariyyetu'ş-şart, 407.

${ }^{41}$ Karadâğî, Mebdeü'r-rizâ, 2: 1167.

42 Senhûrî, Mesâdiru'l-hak, 3: 108.

${ }^{43}$ Serahsî, el-Mebsût, 13: 17; Burhânüddîn el-Buhârî, el-Muhitu'l-burhânî, 6: 391; Kârâfî, el-Furûk, I: 397; Şirbînî, Muğni'l-muhtâc, 2: 43; Remlî, Nihâyetü'l-muhtâc, 3: 453; İbn Âbidîn, Reddü'l-muhtâr, 7: 283; Bilmen, Hukuk-ı İslamiyye ve Istılâhât-ı Fıkhiyye Kâmusu, 6: 24; ZuhaylI: el-Fıkhu'l İslamî, 4: 477.

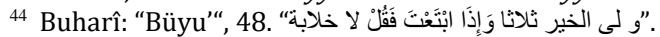

45 Ey İman Edenler! belirlenmiş bir vakte kadar birbirinize borçlandığınız zaman onu yazın...

${ }^{46}$ Kâsânî, Bedâi'u's-sanâi', 7: 23; İbn Nüceym, el-Bahru'r-râik, 6: 140; Şâzelî, Nazariyyetu'ş-şart, 186.

47 Serahsî, el-Mebsût, 13: 17.

${ }^{48}$ Ahmed b. Hanbel, Müsned, 5: 500; İbn-i Mâce, "Büyu'“, 23; Ebû Dâvud, "Büyu'“, 25.

${ }^{49}$ Kâsânî, Bedâi'u's-sanâi', 7: 24; Burhânüddîn el-Buhârî, el-Muhitu'l-Burhânî, 6: 405.
} 
mezheplerde ise bu şartlar, akdin gereğine uygun olarak görülmüş ve sihhati de nas ile temellendirilmiştir. ${ }^{50}$

Burada Zâhirîler'e göre sadece hukukun izin verdiği şartların sahih olduğunu belirtmek gerekir. Bu şartlar yedi tane olup şunlardır: Rehin alma şartı, semenin daha sonra ödenmesini (veresiye) şart koşmak, borcun ödenmesini, bolluk ve zenginlik vaktine kadar geciktirme şartı, satılan malın kusur ve ayılardan salim olmasını ve bazı özelliklere sahip olmasını şart koşmak, Muhayyer olma şartı, bir köle veya câriye satın alındığı vakit, onlara ait malların hepsinin, bir kısmının veya hepsinden belli bir oranın onlarla birlikte verilmesini şart koşma, aşılı hurma ağacı ile birlikte üzerinde bulunan meyvelerin de satışa dâhil edilmesini şart koşmak. Zâhirî mezhebinde bu yedi şartın dışında, akitle birlikte ileri sürülen şartların tümü akitle birlikte bâtıldır. Dolayısıyla akit, zikredilen şartların dışında bir şartla kurulursa feshedilir. Ancak akit, hukuken varlık kazanmadan önce veya sonra ileri sürülen şartlar bâtıl, akit sahihtir. ${ }^{51}$

\subsection{4. Örf Halini Almış Şartlar}

İnsanların akit yaparken teâmül haline getirdiği ve genelde taraflardan birine özel faydası dokunan birtakım şartlar vardır. Bunlar, akdin gereği olmadığı gibi, ona uygun şartlardan da değildir. Bu nedenle geçerliliği konusunda ihtilaf edilmiştir. Satıcının belli bir süre içerisinde arızalanması durumunda sattığı ürünü tamir etmeyi garanti etmesi, eve teslim edilmesi şartıyla mobilya, takılması şartıyla kombi vb. alışverişler günümüzde örfteki uygulamalar olarak değerlendirilebilir.

Genel kurala göre bu şartların sahih olmaması gerekir. Zira bu şartlar, Hanefî ve Şâfiî mezhepleri bașta olmak üzere bazı fakîhlere göre, akdin fesadına yol açan şartlardandır. Çünkü burada akdin gereği olmayan ve taraflardan birine özel fayda sağlayan bir şart söz konusudur. ${ }^{52}$

Hanefî hukukçular, istihsan yöntemine dayanarak örfteki uygulamaları, sahih şartlar kategorisine dâhil ederler. ${ }^{53}$ Şâfî̀ kaynaklarda ilke olarak zikredilmese deama mezhebin bazı hukukçuları örnekler üzerinden bu şartların sahih olduğuna işaret ederler. Mesela, Maverdî’ye (ö. 450/1058) göre evini satan bir şahıs, evi boşaltacak kadar uygun bir süre evde kalmayı şart koşabilir. Ona göre bu hususta kaide; "Örf ile sabit olan, şart ile sabit olmuş gibidir."54 Mâlikî, Hanbelî

\footnotetext{
${ }^{50}$ Nevevî, el-Mecmu', 9: 223; İbn Kudâme, el-Muğnî, 6: 322-323; İbn Receb, el-Kavâid, I: 451; Buhûtî, Keşşâfu'l-kına', 2: 495; Zuhaylî, el-Fikhu'l-Mâlikiyyu'l-müyesser, 2: 396; Abdurrahman Haçkalı, İslam Hukukunda Satım Akdiyle İlgili Şartlar (Yüksek Lisans Tezi: Ondokuz Mayıs ÜniversitesI: 1995), 74.

51 İbn Hazm, el-Muhallâ, 8: 412 vd.; Şâzelî, Nazariyyetu'ş-șart, 322.

${ }^{52}$ Merğînânî, el-Hidaye, 3: 49; İbn Nüceym, el-Bahru'r-râik, 6: 144; İbn Âbidîn, Reddü'l-muhtâr, 7: 286.

${ }^{53}$ Serahsî, el-Mebsût, 13: 15; Kâsânî, Bedâi'u's-sanâi', 7: 17; Burhânüddîn el-Buhârî, el-Muhitu'l-Burhânî, 6: 389-392; İbnu'l-Hümâm, Fethu'l-Kadîr, 6: 404; İbn Nüceym, el-Bahru'r-râik, 6: 140; Bilmen, Hukuk-l İslamiyye ve Istılâhât-ı Fıkhiyye Kâmusu, 6: 23.

${ }^{54}$ MâverdI: Ebu'l-Hasan Ali b. Muhammed b. Habîb, el-Hâvi'l-kebîr fî fikhî mezhebi'l-İmâmi'ş-Şâfiî; şerhu Muhtasari'l-Müzenî, thk. Ali Muhammed Muavviz - Adil Ahmed Abdülmevcûd (Beyrut: Dâru'lKütübi'l-İlmiyye, 1994), 5: 341.
} 
ve Caferî mezheplerinde ise, bu şartlar örf halini almasa da geçerlidir. Zira bu üç mezhepte, akitlerde şart koşma hürriyetinin alanı oldukça geniştir. ${ }^{55}$

Burada örf halini almış şartların sahih olduğunu söylemekle bir açılıma imkân sağlayan Hanefîler'in yaklaşımı önemlidir. Bu sebeple üzerinde durmak gerekir. Hanefiler, şart koşma konusunda temel kuralın yasaklık olduğunu kabul ederler. ${ }^{56} \mathrm{Bu}$ görüşlerinin dayanağı, "Hz. Peygamber şartlı satışı yasaklamıştır."57 rivayetidir. Ayrıca şart koşmak suretiyle taraflardan birine fazladan borç yüklenmesi söz konusudur. $\mathrm{Bu}$ da mezhepte faiz şüphesi olarak değerlendirilmektedir. Buna göre, teâmül haline gelmiş şartların fasit olması gerekir. ${ }^{58}$

Öte yandan bu yaklaşım, hadisin hükmünü örf ile ortadan kaldırma gibi gözükmektedir. Ancak durum böyle değildir. Çünkü hadisten anlaşılan yasağın gerekçesi; taraflar arasında anlaşmazlık çıkmasıdır. Örf ise, anlaşmazlıkları ortadan kaldırmaktadır. O halde burada örf, hadisin değil de genel kıyasın hükmünü ortadan kaldırmıştır. Nitekim Hanefî usulde "Örf ile kıyas terk edilir, nas tahsis edilir." 59

Hanefî mezhebi teoride ca'lî şartların sınırını dar tutmakla birlikte, sahih şartların dayandığı delilleri çoğaltarak (kıyas, maslahat, istihsan, örf) uygulamada bu sınırları genişletmişlerdir. ${ }^{60} \mathrm{Bu}$ cümleden olarak, itibar edilen örfün, genel örf olmasını da şart koşmazlar. Sadece bir yörenin, aynı meslek grubunun veya ticaret erbabının teâmül haline getirdikleri özel örfü bu kapsamda değerlendirirler. ${ }^{61}$ Buradan hareketle önceki dönemlerde fıkıh ve fetva mecmualarında zikredilen örneklerin dışında bir şey, sonradan örf haline gelirse buna itibar edilir. Buna karşılık, bir dönemde örf halini almadığı için fasit olarak değerlendirilen bir şart, daha sonra örf haline gelirse geçerli olur denilebilir. Ancak taraflar arası çekişmeye götüren örf ve âdetler bundan istisna edilir. ${ }^{62}$

Ayrıca Hanefîler, örfteki uygulamaların şart koşulmadan yerine getirilmesinin bizzat akdin gereği olduğunu savunurlar.63 Mecelle'nin 43. maddesinde de yer aldığı üzere, mutlak olarak yapılan hukukî işlemlerde örf dikkate alınır. Mesela, buzdolabı alan müşterinin, eve taşınması konusunda satıcı ile ihtilafa düşmesi durumunda örfün hakemliğine müracaat edilir. Şayet örf, satıcının buzdolabını eve götürmesini gerektiriyorsa buna göre davranmak satıcının yükümlülügündedir. Çünkü mutlak, örf ve adet ile mukayyettir. Ne var ki

\footnotetext{
55 Sahnûn, el-Müdevvene, 3: 202; Küleynî, Muhammed b. Yakub, el-Kâfî (Beyrut: Menșûrâtü'l-Fecr, 2007), 6: 101 vd.; İbn Kudâme, el-Muğnî, 6: 323-326.

${ }^{56}$ Düreynî, Buhûs, 2: 378.

57 Taberânî, el-Evsat, 4: 335 (4361).

58 İbn Nüceym, el-Bahru'r-râik, 6: 144; İbn Âbidîn, Reddü'l-muhtâr, 7: 286.

${ }^{59}$ Merğînânî, el-Hidâye, 3: 49; Burhânüddîn el-Buhârî, el-Muhitu'l-Burhânî, 6: 391; İbn Âbidîn, Reddü'lmuhtâr, 7: 286; İbnü'l-Hümâm, Fethu'l-Kadîr, 6: 405.

${ }^{60}$ Düreynî, Buhûs, 2: 378.

${ }^{61}$ Zerkâ, el-Medhal, 2: 925; Şâzelî, Nazariyyetu'ş-şart, 187.

${ }^{62}$ İbn Âbidîn, Reddü'l-muhtâr, 7: 286.

${ }^{63}$ Burhânüddîn el-Buhârî, el-Muhitu'l-Burhânî, 6: 403
} 
örfteki uygulamalar, irade beyanı ile iptal edilebilir. Akit anında şayet müşteri satıcının eve teslim etmeme şartını kabul ederse, artık örfe itibar edilmez. ${ }^{64}$

Günümüzde akitlerde daha önce görülmeyen bazı şartlar ileri sürülmektedir. Bunlar, satılan ürünlerin çoğunda belirli bir süre garanti şartı, eve teslim edilmesi, kurulumunun yapılması vb. örf halini almış, toplum için yararlı uygulamalardır. Zira bu durum, malın sürümünü artırmakta, müşterinin de güvenli alışveriş yapmasına imkân sağlamaktadır. Bu sebeple toplumsal yararın sağlanması ve ihtiyaçların giderilmesi açısından örfteki uygulamaların ayrıca şart koşulmadan akitle birlikte gerekli kılınması yönündeki görüşlerin daha isabetli olduğu kanaatindeyiz. Zira örf, yaşanan tecrübelerin neticesi olması ve ticarî hayatı büyük ölçüde istikrara kavuşturması yönleriyle toplumda özel bir öneme sahiptir. Ayrıca, taraflar örfteki uygulamaların ne kazandırıp ne kaybettirdiğini bildikleri için, aldanma riski de daha aza inmektedir.

Teâmül haline gelmiş şartların geçerli sayılması, akitlerde şart koşma hürriyetinin sınırlarını genişletme bakımından önemlidir. Bazı İslam hukukçuları bunu, şart hürriyetinin kapılarını ardına kadar açmak olarak nitelerken, bazıları da hukuka aykırı olanlar hariç fasit şart kalmadığını söylemektedir. 65

\subsubsection{Hayır ve İyilik Manasına Gelen Bir Şeyi Gerekli Kılan Şartlar}

İslam hukukunda akit konusu malın vakıf, hibe veya tasadduk edilmesini şart koşma vb. hayır manasında bir iş yapmayı gerekli kılan şartların sıhhati konusunda ihtilaf edilmiştir. Ebû Hanife'ye göre bu şartlar sahihtir. İmameyn ise bu şartların fasit olduğunu savunurlar. Bu ihtilafın sebebi, ileri sürülen şartın, akdin gereğine uygun olup olmadığıdır. Zira akit, mülkiyetin el değiştirmesini ve mutlak tasarrufu gerektirir. Ancak bu şart hem tasarrufu kısıtlamakta hem de alıcının mülkünden çıkmasını gerekli kılmaktadır. ${ }^{66}$

Mâlikî mezhebinde bu şartlar esas itibariyle akdin gereğini ortadan kaldırmaktadır. $\mathrm{Bu}$ nedenle akitle birlikte geçersiz olmaları gerekirken, sahih şartlar kapsamında ele alınmıştır. Onlara göre Şâri', köle azadı başta olmak üzere hibe, tasadduk vb. şeylerin yapılmasını teşvik etmiştir. Dolayısıyla hayır ve iyilik manası taşıyan şartlar istisnaî bir durum olarak sahih ve bağlayıcıdır. ${ }^{67}$ Ayrıca bu şartların sahih olması için zamana izâfe edilmemesi gerekir. Şayet daha sonraki bir zaman diliminde akit konusunun hibe, hediye veya tasadduk edilmesi şart koșulursa, bu sahih değildir. Çünkü bunda belirsizlik (garar) söz konusudur. ${ }^{68}$

${ }^{64}$ Zeydân, Abdülkerim, el-Vecîz fî șerhi'l-kavâidi'l-fikhîyye (Beyrut: Müessesetü'r-Risâle, 2014), 101; Köse, Saffet, İslam Hukukuna Giriş (İstanbul: Hikmetevi Yayıne6: 2017), 136; Zuhaylî, el-Fıkhu'lÍslamî, 7: 372.

${ }^{65}$ Düreynî, Buhûs, 2: 379.

${ }^{66}$ Merğînânî, el-Hidâye, 3: 49; Burhânüddîn el-Buhârî, el-Muhitu'l-Burhânî, 6: 392; İbn Âbidîn, Reddü'lmuhtâr, 7: 284.

${ }^{67}$ İbn Rüșd el-Cedd, Ebu'l-Velîd Muhammed b. Ahmed, el-Beyân ve't-tahsîl, 14: 330; İbn Rüşd el-Hafîd, Bidayetü'l-müçtehit, 3:1641; Zuhaylî, el-Fıkhu'l-Mâlikiyyu'l-müyesser, 2: 396.

${ }^{68}$ Şâzelî, Nazariyyetu'ş-şart, 226. 
Şâfiî mezhebinde ihtilaflı olmakla birlikte yaygın kanaat bu şartların sahih olduğu yönündedir. Ancak bu şartların akit konusu dışında bir şey için şart koşulması sahih değildir. Buna göre, satılan evin dışında başka bir şeyin vakfedilmesini şart koşmak geçersizdir. ${ }^{69}$ Caferî ve İbâziyye mezheplerinde de aynı gerekçelerle bu şartlar geçerlidir. ${ }^{70}$ Zeydîler'e göre ise bu şartlar bâtıl (lağv), akit geçerlidir. Bununla birlikte şartın gereği yasak/haram değilse yerine getirilmesi menduptur. ${ }^{71}$

\subsection{Fâsit Şartlar}

Fasit şartlar, akdin de fesadına yol açan şartlardır. Bu şartları altı başlık altında ele almak mümkündür.

\subsubsection{Akdin Gereği Olmayan Şartlar}

Bizzat akdin gereği olmayan, ona da uygun olmayan şartların geçerliliği konusu İslam hukukçuları arasında ihtilaflıdır.

Hanefî mezhebinde, bu şartlar genel kıyasa aykırı olarak değerlendirildiği için fasit görülmüştür. ${ }^{72}$ Mesela satım akdinde akit konusu malın daha sonra teslim edilmesini şart koşmak böyledir. Çünkü bedelli akitler, mülkiyetin derhal el değiștirmesini gerektirir. ${ }^{73}$ Şâfiî ve Zeydiyye mezheplerinin görüşü de budur. ${ }^{74} \mathrm{Bu}$ yaklaşım, "Peygamberimiz şartlı satışları yasaklamıştır"75 hadisine dayanır.76 Hanefîler'e göre böyle bir şartla birlikte kurulan akit fasittir. Fakat şartı koşan tarafın bu şarttan vazgeçmesiyle, akit geçerlilik kazanır.77 Şâfiî mezhebinde ise şarttan vazgeçilse bile akit geçerli olmaz. ${ }^{78}$

Mâlikî mezhebinde bu şartlardan belirsizlik (garar) ve cehâlete yol açan, taraflar arasında anlaşmazlığa götüren ya da mülkiyet ve tasarruf hakkını tamamen engelleyen şartlar fasittir. Örneğin, akit konusu malın bilinen bir veya birkaç kişiye satılmamasını şart koşmak sahihtir. Zira onlara göre, satılan malda az bir tasarruftan alıkoymak akdin gereğine aykırı değildir.79 Mâlikîler, bu

\footnotetext{
${ }^{69}$ Nevevî, el-Mecmu', 9: 448; Remlî, Nihâyetü'l-muhtâc, 3: 451, 456; Şâzelî, Nazariyyetu'ş-şart, 255.

70 Küleynî, el-Kâfî, 5: 100; Şâzelî, Nazariyyetü'ş-şart, 379.

71 San'ânî, et-Tâcu'l-müzehheb, 2: 377.

72 Serahsî, el-Mebsût, 13: 15; Merğînânî, el-Hidâye, 3: 48; İbn Nüceym, el-Bahru'r-râik, 6: 139; Bilmen, Hukuk-ı İslamiyye ve Istılâhât-ı Flkhiyye Kâmusu, 6: 24.

${ }^{73}$ Kâsânî, Bedâi'u's-sanâi', 7: 24; İbnu'l-Hümâm, Fethu'l-Kadîr, 6: 412; Meydânî, Abdulğanî el-Ğanîmî, elLubab fi şerhi'l-Kitab, thk. Abdurrezzak el-Mehdî (Beyrut: Dâru'l-kitâbi'l'Arabî, 2010), I: 213.

${ }^{74}$ Müzenî, Ebu İbrahim İsmail b. Yahya b. İsmail, Muhtasaru'l-Müzenî fi fürûi'ş-ŞâfiiyyetI: thk. Muhammed Abdülkadir Şahin (Beyrut: Dâru'l-Kütübi'l-İlmiyye, 1998), 123; Nevevî, el-Mecmu', 9: 453; Şirbînî, Muğni'l-muhtâc, 2: 43-46; San'ânî, et-Tâcu'l-müzehheb, 2: 370; Şâzelî, Nazariyyetu'ş-şart, 263-265.

75 Taberânî, el-Evsat, 4: 335 (4361).

76 Nevevî, el-Mecmu', 9: 452.

77 Serahsî, el-Mebsût, 13: 15; Merğînânî, el-Hidâye, 3: 48; İbn Nüceym, el-Bahru'r-râik, 6: 139.

${ }^{78}$ Nevevî, el-Mecmu', 9: 455.

79 İbn Rüșd el-Cedd, el-Beyân ve't-tahsîl, 6: 267, 330; Zuhaylî, el-Fikhu'l-Mâlikiyyu'l-müyesser, 2: 396; Karadâğî, Mebdeü'r-rızâ, 2: 1173.
} 
yaklaşımlarını Câbir (r.a) hadisine dayandırırlar. ${ }^{80}$ Onlara göre bu rivayet, satım ve kira sözleşmesinin bir akitte toplanmasının caiz olduğunu gösterir. Zira $\mathrm{Hz}$. Peygamber (s.a.s) deveyi satın alarak bir satım akdi ve Câbir'in (r.a) Medine'ye kadar deveye binmesi şeklinde de bir kira akdi yapmıştır. Bu iki akdin bir arada yapılması caiz olduğuna göre, taraflardan birinin akit konusu maldan belirli bir müddet az bir menfaati şart koşması da caiz olur. ${ }^{81}$

Ayrıca mezhepte takyîdî şartın akitlere etkisi faiz, garar ve mülkiyeti engelleme derecesine bağlıdır. Şayet şart akitlerde bu üç şeyden birine çok miktarda sebebiyet veriyorsa akit de şart da batıl, orta miktarda etkisi varsa şart geçersiz akit sahih, az miktarda etkisi varsa her ikisi de geçerlidir. ${ }^{82}$

$\mathrm{Bu}$ şartlardan iyilik ve hayır manasında bir şeyi gerekli kılanlar hariç, diğerleri Hanbelî mezhebine göre de fasittir. Ancak akdin fesadını gerektirmez. Onlara göre, şartı koşan taraf $e r s^{83}$ alma ve akdi feshetme arasında muhayyerdir. Zira şartı koşan taraf akit yapmaya bu şartla birlikte razı olmuştur. Şartın gerçekleşmemesi rızayı ortadan kaldırdığından akdi feshetme hakkı olur. Aynı şekilde akitle birlikte ileri sürülen şartın semenden karşılığı olduğu için de erş almaya hak kazanır.84 İbn Teymiyye (ö.728/1327), sahih bir maksadı gerçekleștiriyorsa, akdin gereği olmasa bile şartın geçerli olduğunu savunur. ${ }^{85}$

\subsubsection{Garar ve Cehâlete Yol Açan Şartlar}

Garar, akit konusunun meydana gelip gelmeyeceği (mestûru'l-'âkibe) veya bedellerin ödeme gününde aşırı bilinmezlik içermesi olarak tanımlanmaktadır. ${ }^{86}$ Farklı bir tabirle garar, bir borç ilişkisinde akde konu olan şeyin haksız kazanca yol açacak ölçüde belirsizlik taşıması, akıbetinin kapalı olması demektir. ${ }^{87}$ Cehâlet ise konu veya bedel bakımından akdin bilinmezlik içermesidir. Gökteki kuş, denizdeki balı satım konusu olursa garardan, mevcut ama akit meclisinde bulunmayan ve bilinmeyen bir şeyin satılması halinde cehâletten bahsedilir. ${ }^{88}$ Buna göre garar, akit konusunun elde edilip edilemeyeceğinin bilinmemesiyle ilgili bir terimken,

\footnotetext{
${ }^{80}$ Hanefî fakîhler, Câbir'den (r.a) gelen rivayette öne sürülen şarta, yolculukta zaruret sebebiyle izin verildiğinI: bunun ruhsat olduğunu ve bu konudaki hükmün "Peygamberimiz şartlı satışları yasaklamıştır" $80 \quad$ rivayetinde açıklandığını savunurlar. ${ }^{80}$

81 İbn Rüşd, Bidâyetü'l-müctehid, 3: 1641.

82 İbn Rüşd el-Cedd, Ebu'l-Velîd Muhammed b. Ahmed, el-Mukaddimâtü'l-mümehhidât, thk. Muhammed Haccî (Beyrut: Dâru'l-Ğarbi'l-İslâmî, 1998), 2: 67; İbn Rüşd, Bidâyetü'l-müctehid, 1640.

${ }^{83}$ Erş: Ayıplı olduğu ortaya çıkan malın bedelinden düşülen miktar.

${ }^{84}$ İbn Kudâme, el-Muğnî, 6: 325; Buhûtî, Keșşâfu'l-kına', 2: 498- 499; İbn Teymiye, Takiyuddin Ahmed b. Abdulhalim, Mecmûatu'l-fetâvâ, thk. Âmir el-Cezzar - Enver el-Bâz (Riyad: Mecma'u'l-Melik Fehd li'ttıbâa, 2005), 29: 187.

85 İbn Teymiyye, el-Fetâvâ, 4: 102; Şâzelî, Nazariyyetu'ş-şart, 318.

${ }^{86}$ Serahsî, el-Mebsût, 13: 68; Zuhaylî, el-Fıkhu'l-İslamî, 5: 95.

${ }^{87}$ Siddîk Muhammed el-Emîn ed-Darîr, el-Garar ve eseruhû fi'l-'ukûd fi'l-fikhî'l-İslâmî (Y.y.: Albaraka YayınlarI: 1990), 54; Karaman, Mukayeseli İslam Hukuku, 2: 167; Necmeddin Güney, Satım Akdi Özelinde İslam Borçlar Hukukunda Garar (Doktora TezI: Necmettin Erbakan ÜniversitesI: 2013), 63.

${ }^{88}$ Karâfî, el-Furûk, 3: 403.
} 
cehâlet akde konu olan şeyin kendisiyle ilgili değil, vasıfları hakkında bilinmezliktir. ${ }^{89}$

İslam hukukçularına göre garar ve cehâlete yol açan şartlar, akitle birlikte fasittir. Çünkü garar yasağı Kitap, sünnet ve icma ile sabittir. ${ }^{90}$ Ayrıca garar ve cehâlet taraflar arası anlaşmazlığa yol açar. Çok süt vermesi, gebe olması, sütünü sağdırması şartıyla bir hayvan satın almak; şu kadar yağ içermesi şartıyla zeytin veya susam almak böyledir. ${ }^{91}$ Örneklerden de anlaşıldığı üzere ileri sürülen bu şartların akit anında bilinmesi mümkün değildir. Mesela günde $10 \mathrm{~kg}$. süt vermesi şartıyla satılan bir hayvanın, akitten sonra ne kadar süt vereceği bilinmez. Durum, şart koșulanın aksine çıkabilir. Bu da anlaşmazlığa sebebiyet verir. ${ }^{92}$

Dikkat edilirse bu şartlar, sahih şartlar başlığı altında incelediğimiz; akit konusu malda aranan bir niteliğin şart koşulması kabilinden olup, kendilerine mecâzen şart denilen şartlara benzemektedirler. Miktarı belirtilmeden ileri sürülen bu vb. şartların gerçekte olup olmadığı, bu işin uzmanlarından yardım alınarak bilinebilir. Mesela, süt vermesi şartıyla satılan hayvanın bu durumu veteriner yardımıyla bilinebilir. Buna karşılık kaç kg. süt verdiği bilinemez. Bilinemediği için de burada belirsizlik (garar) ve bilinmezlik (cehâlet) olur ki, bu da anlaşmazlığa yol açar. Ayrıca garar ve cehâletin alanı, hayat düzeninin gelişmesine, insanın bilgisinin ve tecrübelerin artmasına bağlı olarak daralır ve genişler. Hukukî işlemlerde örfün değişmesi de aynı şekilde garar ve cehâletin alanını etkiler. İlim alanı genişledikçe, tecrübeler arttıkça, insanların örf ve âdetleri yerleștikçe bu alanın daraldığı görülür. Bunun aksi olduğunda ise daha da genişler. ${ }^{93}$

Burada dikkat edilmesi gereken nokta şudur: Şartlardaki garar ve cehâlet, taraflar arası çözümü güç bir anlaşmazlığa yol açacak kadar olursa akit fasittir. Ancak böyle bir şey olmayacaksa şart da akit de sahih olur. ${ }^{94}$

\subsubsection{Hukuken Yasak Olan Bir Şeyi İçeren Şartlar}

Kanun koyucunun yasakladığı, insanları din ve dünya işlerinden alıkoyan, meşru bir gayeye yönelik olmayan bir şeyin şart koşulması geçersiz olup, akdi de ifsad eder. ${ }^{95}$ Dövüşken olması şartıyla koç veya horoz, güzel ses çıarması şartıyla kumru vs. satın almak böyledir. Çünkü bu gibi şartlarda meşru bir amaç yoktur.

${ }^{89}$ Garar-cehâlet ilişkisi hakkında detaylı bilgi için bk. Güney, Satım Akdi Özelinde İslam Borçlar Hukukunda Garar, 80 vd.

${ }^{90}$ Ahmed b. Hanbel, Müsned, 5: 500; İbn-i Mâce, "Büyû'“, 23; Ebû Dâvud, "Büyu'“, 25.

${ }^{1}$ Sahnûn, el-Müdevvene, 3: 190; Serahsî, el-Mebsût, 13: 19; Kâsânî, Bedâi'u's-sanâi', 7: 3; Meydânî, elLübâb, I: 214; Şirbînî, Muğni'l-muhtâc, 2: 43; Remlî, Nihâyetü'l-muhtâc, 3: 453; Buhûtî, Keşşâfu'l-kına', 2: 497.

92 Serahsî, el-Mebsût, 13: 20; Kâsânî, Bedâi'u's-sanâi', 7: 11; Burhânüddîn el-Buhârî, el-Muhitu'l-Burhânî, 6: 396.

93 Şâzelî, Nazariyyetu'ş-şart, 190.

94 Kâsânî, Bedâi'us-sânaî', 6: 592; İbn Rüșd, Bidâyetü'l-müctehid, 3: 1640.

95 Sahnûn, el-Müdevvene, 3: 190; Kâsânî, Bedâi'u's-sanâi', 7: 11; Bilmen, Hukuk-ı İslamiyye ve Istılâhât-ı Fıkhiyye Kâmusu, 6: 24. 
Hukuken yasaklanan bir sonuca ulaştırdığı için, akdin meşru kılınma sebebine de uygun değildir. ${ }^{96}$

İnsanları din ve dünya işlerinden alıkoyması, bu şartların en belirgin özelliğidir. Bununla birlikte, bu şartların bir kısmı garar ve cehâlet içerir. Mesela, horozun dövüşçü olmasının vb. tespiti zordur. Dolayısıyla hem hukuken yasaklandığı için hem de akit konusundaki belirsizlikten dolayı geçersizdir. ${ }^{97}$

Burada şu hususa dikkat çekmeliyiz. Din ve dünya işlerinden alıkoyan ve hukukun yasakladığı bu özelliklerin akit konusu malda bulunması, mutlak manada fesadı gerektirmez. Ancak bu özelliklere rağbet edilerek, şart koşulması fasittir. Bu nedenle ayıbını ifade etmek için, hayvanın dövüşçü olduğunu söylemek bu kapsamda değildir. Bu durumda hayvan dövüşçü çıkmasa bile akit geçerlidir. Çünkü bu ayıplı halde alınan bir şeyin kusursuz çıkması gibidir. Dolayısıyla sorumlu olmama maksadıyla ayıbın zikredilmesi akdin sıhhatine engel olmaz. ${ }^{98}$

\subsubsection{Hukuken (Şer’an) Yasaklanan Bir Şeye Götüren Şartlar}

İslam hukuk usûlünde kendi başına düşünüldüğünde hukuka uygun olmakla birlikte, çoğunlukla hukuken yasaklanmış kötü ve zararlı sonuçlara yol açan vesilelerin yasaklanması esastır. Fıkıh usûlü terminolojisinde buna sedd-i zerâi denir. ${ }^{99}$

$\mathrm{Bu}$ esasa göre özü itibariyle meşru olan bir fiilin yasak olan bir sonuca götürmesi kuvvetle muhtemelse, kendisi de yasaklanır. Bu nedenle şarap yapma şartıyla üzüm, adam öldürme şartıyla silah satılması vb. sahih değildir. Çünkü bu şartların meşru olmayan bir sonuca yol açacağı kesindir. Ancak hukukun yasakladığı bir neticeye yol açması kesin olmayan şartların akitle birlikte ileri sürülmesi sahihtir. Hatta Şâfiîler, şarap üretimi yaptı̆̆ bilinen bir kimseye mutlak olarak üzüm satışının caiz olduğunu savunurlar. ${ }^{100}$

\subsubsection{Taraflara Yarar Sağlayan Şartlar}

$\mathrm{Bu}$ şartlar, akdin gereği olmayan, onu kuvvetlendirmeyen, örfteki uygulamalardan olmayan ve akdi yapan taraflardan birine özel menfaat sağlayan şartlardır. ${ }^{101}$ Satıcının bir süre kullanma şartıyla bilgisayarını satması, müşterinin boyanıp temizlenmesi şartıyla araba satın alması vb. böyledir.

Klasik kaynaklarda bu şartlar, menfaat sağladığı kişiye nispetle üçe ayrılır. Satıcıya, müşteriye ve akdin konusuna ${ }^{102}$ özel menfaat sağlayan şartlar. ${ }^{103}$ Bir süre

${ }^{96}$ Burhânüddîn el-Buhârî, el-Muhitu'l-Burhânî, 6: 397-398; Nevevî, el-Mecmu', 9: 446 vd.; Şirbînî, Muğni'l-muhtâc, 2: 46.

97 Muvatta, "Büyû'“, 6; Kâsânî, Bedâi'u's-sanâi', 7: 11; Şâzelî, Nazariyyetu'ş-şart, 191; Zuhaylî, el-Fıkhu'lMâlikiyyu'l-müyesser, 2: 396.

98 Kâsânî, Bedâi'u's-sanâi', 7: 12; Burhânüddîn el-Buhârî, el-Muhitu'l-Burhânî, 6: 397.

${ }^{99}$ Kârâfî, el-Furûk, 2: 32.

${ }^{100}$ Nevevî, el-Mecmu', 9: 446 vd.; Şirbînî, Muğni'l-muhtâc, 2: 46.

${ }^{101}$ Kâsânî, Bedâi'u's-sanâi', 7: 12; İbnu'l-Hümâm, Fethu'l-Kadîr, 6: 405-406; Bilmen, Hukuk-ı İslamiyye ve Istılâhât-ı Flkhiyye Kâmusu, 6: 24.

${ }^{102}$ Akdin konusu köle ve cariye gibi haklara sahip olabilen durumlarda böyle bir şart söz konusu olur. 
oturma şartıyla ev, belirli mesafe binme şartıyla araç, bir müddet kullanma şartıyla herhangi bir eşyayı satmak satıcıya yararı dokunan şartlar kapsamında ele alınır. Satıcının, müşteriden kendisine borç (karz) vermesini şart koşması da böyledir.

Akit konusu malda müşterinin menfaatine olan bir iş yapmayı gerekli kılan ve müșterinin lehine satıcıyı bașka bir akit yapmaya zorlayan şartlar da müşteriye faydası dokunan şartlar arasında zikredilebilir. Ögütülmesi şartıyla buğday, toplanması şartıyla meyve, kesilmesi veya dikilmesi şartıyla kumaş satın almak böyledir. Müşterinin, satıcıdan kendisine ödünç para vermesini veya bedelden bir şey hibe etmesini şart koşması da bu kapsamda ele alınır. ${ }^{104}$

İslam hukukunda bu şartların sıhhati konusunda ihtilaf edilmiştir. Konuyla ilgili temelde iki farklı yaklaşım söz konusudur. Hanefî mezhebinde bu şartların tespitinde farklı görüşler bulunmakla birlikte şartlar ittifakla fasittir. ${ }^{105}$ Ancak daha önce geçtiği üzere bu şartlardan akit konusu mal üzerinde ikinci bir iş yapmayı gerekli kılan ve örf haline gelmiş şartlar (buğdayın öğütülmesi, kumaşın dikilmesi vb.) her ne kadar taraflardan birine özel menfaat sağlasa da bu genel hükümden istihsânen- istisna edilmiştir. ${ }^{106}$

Şâfiî mezhebinde İbn Huzeyme (ö. 311/924) ve İbn Münzîr (ö.319/931) gibi hukukçulara göre bu şartlar sahihtir. Bu iki hukukçunun dayanağı Câbir (r.a) hadisidir. Ancak, mezhepte sahih görüş bunun aksinedir. ${ }^{107}$ Mâlikî, Hanbelî ve Caferî hukukçulara göre, bu şartlar geçerli ve tarafları bağlayıcıdır. Ayrıca Hanbelî mezhebinde bu şartlar taraflardan herhangi biri lehine koşulabildiği gibi, üçüncü şahıslar için de ileri sürülebilir. ${ }^{108}$

İslam hukukçularının bu farklı yaklaşımları, konuyla ilgili rivayetleri anlama ve yorumlamadaki farklılıktan kaynaklanmaktadır. Mesela Mâlikî hukukçular bu şartların sahih olduğunu şu şekilde izah ederler: Taraflardan birine özel yarar sağlamasına rağmen bu şartlar akdin gereğine tamamen aykırı değildir. Çünkü burada kişinin mülkünde mutlak olarak tasarruftan engellenmesi söz konusu değildir. Mesela, satılan bir evde bir müddet oturmayı şart koşmak, evin müşterinin mülküne geçmesini engellemediği gibi, hiçbir tasarrufta bulunmamasını da gerekli kılmıyor. Burada az bir engelleme varsa da bu akdin sıhhatine zarar vermez. Mâlikîler bu konuda Câbir (r.a) hadisini esas alırlar. ${ }^{109}$

\footnotetext{
${ }^{103}$ Kâsânî, Bedâi'u's-sanâi', 7: 12; İbnu'l-Hümâm, Fethu'l-Kadîr, 6: 405-406; Bilmen, Hukuk-ı İslamiyye ve Istılâhât-ı Fıkhiyye Kâmusu, 6: 24.

${ }^{104}$ Serahsî, el-Mebsût, 13: 15; Merğînânî, el-Hidâye, 3: 49; Burhânüddîn el-Buhârî, el-Muhitu'l-Burhânî, 6: 394-395, 402; İbn Nüceym, el-Bahru'r-râik, 6: 140; Meydânî, el-Lübâb, I: 214.

105 Şeybânî, el-Asl, 2: 441; Serahsî, el-Mebsût, 13: 15; Kâsânî, Bedâi'u's-sanâi', 7: 12; Burhânüddîn elBuhârî, el-Muhitu'l-Burhânî, 6: 394-395; İbnü'l-Hümâm, Fethu'l-Kadîr, 6: 405; İbn Nüceym, el-Bahru'rrâik, 6: 141; Dâmâd, Abdurrahman b. Muhammed b. Süleyman, Mecma'u'l-enhur fí şerhi Mülteka'lebhur, thk. Muhammed Ahmed el-Muhtâr (Beyrut: Dâru'l-Kütübi'l-ilmiyye, 2016), 2: 111; İbn Âbidîn, Reddü'l-muhtâr, 7: 284.

${ }^{106}$ Merğînânî, el-Hidaye, 3: 49; İbn Nüceym, el-Bahru'r-râik, 6: 144; İbn Âbidîn, Reddü'l-muhtâr, 7: 286.

${ }^{107}$ Nevevî, el-Mecmu', 9: 454, 460; Şirbînî, Muğni'l-muhtâc, 2: 42.

108 Sahnûn, el-Müdevvene, 3: 191; Küleynî, el-Kâfî, 5: 100; İbn Rüşd el-Cedd, el-Mukaddimât, 2: 67; Buhûtî, Keşşâfu'l-kına', 2: 497; İbn Teymiyye, el-Fetâvâ, 4: 81; İbn Receb, el-Kavâid, I: 231-233; Hâşim Ma'rûf, Nazariyyetü'l-akd, 431.

${ }^{109}$ İbn Rüşd, Bidâyetü'l-müctehid, 3: 1641.
} 
Hanbelîler "Hz. Peygamber (s.a.s) şartlı satımı yasakladı" 110 rivayetini sahih kabul etmedikleri için ca'lî şartlar konusunda diğer İslam hukukçularına göre sınırı geniş tutmuşlardır. Bu şartların sıhhatini şu şekilde temellendirmektedirler:111 Onlar, bu şartların fasit olduğunu savunanların aksine Câbir (r.a) hadisinde alışverișin tamamlandığını ve Câbir'in (r.a) kendi menfaatine olarak Medine'ye kadar deveye binmeyi şart koştuğunu, Hz. Peygamber'in (s.a.s) de bunu kabul ettiğini savunurlar. Bir başka dayanakları ise; "Hz. Peygamber (s.a.s) alışverişte istisnadan yasakladl, fakat istisna edilen şey belirli olursa müstesna"112 rivayetidir. Dolayısıyla mübâh ve belirli olması kaydıyla bu şartları sahih kabul ederler. Ümmü Seleme'nin (r.a), Sefine'yi (r.a) yaşadığı müddetçe Hz. Peygamber'e (s.a.s) hizmet etmesi şartıyla azat ettiğine dair rivayet Hanbelîler'in dayandığı bir başka delildir. Onlara göre, kölenin azat edilip hizmetinin istisna edilmesi, satım ve diğer akitlerde menfaatin bir müddet taraflardan biri lehine istisna edilmesi gibidir. ${ }^{113}$

Hanefiler, Câbir (r.a) hadisinde geçen şarta (deveye binme) Hz. Peygamber'in (s.a.s) izin vermesini ruhsat olarak yorumlarlar ve "Hz. Peygamber (s.a.s) şartlı satımı yasakladı"114 hadisini esas alırlar. ${ }^{115}$ Ayrıca Hanefîler'in bir kısmına göre, Hz. Peygamber (s.a.s) ile Câbir (r.a) arasında geçen konuşma akdin gerçekten yapılmadığını gösterir. Onlara göre bu, yolculukta şakalaşma ve güzel sohbette bulunmaktan ibarettir. Medine'ye geldiklerinde Hz. Peygamber'in (s.a.s) Câbir'e (r.a) parayı verdikten sonra; "Deveni de al bu senin malındır" demesi bunu göstermektedir. Akit yapılmadığına göre akitle birlikte koşulan şartın bir hükmü olmadığı gibi bu hadis taraflardan birine menfaati dokunan şartların sıhhati için hüccet olamaz. Bundan başka Hanefilere göre akit, satın alınan malda mutlak manada tasarrufu gerektirir. $\mathrm{Bu}$ șartlar ise tasarrufu kısmen veya tamamen engelleyerek, akdin gereğiyle çelişmektedir. $\mathrm{Bu}$ da taraflar arası anlaşmazlığa sebebiyet vereceğinden şartın sıhhatini engellemektedir. ${ }^{116}$

Hanefilerin bu şartlarla ilgili farklı bir izahı da şöyledir: Bu gibi şartların ileri sürülmesi, taraflardan biri lehine akitle birlikte şart koşulmuş, karşıllğı olmayan fazladan bir menfaattir. Karşılığı olmayan her fazlalık ise riba (faiz) olup akdi ifsad eder. Dolayısıyla burada en azından riba şüphesi vardır. Faizin kendisi olduğu gibi şüphesi de akitlerde fesat sebebidir. ${ }^{117}$ Ayrıca bu şartlar birden fazla akdin bir akitte birleşmesine yol açmaktadır. Bir süre kullanılması şartıyla araç satılması durumunda bu şartın bedelden bir karşılığı varsa yapılan işlem kira sözleşmesi, karşılığı yoksa iâredir. Her iki durumda da bir akitte iki akit (safkatân fî safka) söz konusu olmaktadır. Bunun da yasak olduğu sünnetle sabittir. ${ }^{118}$

\footnotetext{
${ }^{110}$ Taberânî, el-Evsat, 4: 335 (4361).

${ }^{111}$ Buhûtî, Keșşâfu'l-kına', 2: 497; İbn Teymiyye, el-Fetâvâ, 4: 80.

${ }^{112}$ Nesâî, "Büyû'“', 34.

113 İbn Teymiyye, el-Fetâvâ, 4: 79; Buhûtî, Keşşâfu'l-kına', 2: 496; İbn Receb, el-Kavâid, I: 232.

114 Taberânî, el-Evsat, 4: 335 (4361).

115 İbn Nüceym, el-Bahru'r-râik, 6: 144; İbn Âbidîn, Reddü'l-muhtâr, 7: 286.

${ }^{116}$ Serahsî, el-Mebsût, 13: 14; Bilmen, Hukuk-ı İslamiyye ve Istılâhât-ı Fıkhiyye Kâmusu, 6: 24.

${ }^{117}$ Kâsânî, Bedâi'u's-sanâi', 7: 12; İbnu'l-Hümâm, Fethu'l-Kadîr, 6: 406; Zuhaylî, el-Fılkhu'l-İslamî, 4: 481.

${ }^{118}$ Serahsî, el-Mebsût, 13: 16; Kâsânî, Bedâi'u's-sanâi', 7: 22; İbnü'l-Hümâm, Fethu'l-Kadîr, 6: 410
} 
Akit konusu malda bir iş yaptırmayı gerekli kılan şartlar ve bedellerden belirli bir şeyi istisna etmeyi şart koşmak da bu kapsama dâhil edilebilir. Bazı kaynaklarda bunlar ayrı başlıklar altında ele alınmışsa da mahiyeti itibariyle taraflara menfaat sağlayan şartlar olduğu açıktır. Bu sebeple bunların ayrıca zikredilmesine gerek yoktur. ${ }^{119}$ Bedellerden bir şeyin istisna edilmesi ile ilgili kural; "tek başına satılması geçerli olanın istisna edilmesi de sahihtir" şeklindedir. ${ }^{120}$

Şu kadar var ki bu şartların geçerliliği konusunda belirleyici husus; taraflar arası anlaşmazlığa yol açıp açmamasıdır. Bununla birlikte taraflardan birine özel menfaat sağladığı halde örfteki uygulamalar geçerlidir. ${ }^{121}$

\subsubsection{Akitle Birlikte Başka Bir Akdin Yapılmasını Şart Koşmak}

Bir akit içinde başka bir akdin yapılmasını şart koşmak, klasik fıkıh doktrininde safkateyn yasağı olarak bilinmektedir. Bu yasağın dayanağı, konuyla ilgili "Rasûlullah (s.a.s), bir satış/akit içinde iki satış/akit yapılmasını yasakladı."122 şeklindeki rivayetlerdir. Ne var ki yasağı konu edinen hadisler genel nitelikli ifadelerle vârid olmuştur. Ayrıca yasağın mahiyeti ve boyutları konusunda herhangi bir açıklama, tahsis ya da illet beyanında bulunulmamıştır. Bu nedenle İslam hukuk bilginleri, safkateyn şeklinde yapılan akitlerin yasak olduğu konusunda ittifak halindeyken, yasağın çerçevesi ve mahiyeti konusunda farklı yaklaşımlar sergilemişlerdir. Neticede yasağın kapsamını olabildiğince geniş tutanlar olduğu gibi, dar bir çerçeveye hasredenler de olmuştur. ${ }^{123}$

Hanefî mezhebinde, safkateyne üç farklı mana yüklendiği görülmektedir. Bunlardan biri, semen ve vadedeki belirsizlik bulunduran "birden çok fiyat seçeneği sunulan" akittir. Biri peşin diğeri vadeli iki farklı ödeme seçeneğinin sunulması ve bunlardan biri belirlenmeden akdin tamamlanması bunun örneğidir. İkincisi, şart koşma hürriyeti kapsamında taraflara tanınan akdin muhtevasını düzenleme serbestisi ile ilgili olarak "bir akit içinde akit manasına gelen bir menfaatin şart koşulması"dır. Bunun örneği, örfte olmadığı halde satın alınan malın/ürünün taşınmasını, kurulumunu vb. şart koşmaktır. Üçüncü ise "varlık kazanmaları birbirine bağlı iki akdin tek bir sözleşme içinde yapılması"dır. Evini satan kişinin müşteriden kendisine arabasını satmasını şart koşması böyledir. Buna göre

\footnotetext{
${ }^{119}$ Şeybânî, el-Asl, 2: 442; İbnü'l-Hümâm, Fethu'l-Kadîr, 6: 412; İbn Rüșd, Bidâyetü'l-müctehid, 3: 1641; İbn Nüceym, el-Bahru'r-râik, 6: 143; İbn Kudâme, el-Muğnî, 6: 323; İbn Receb, el-Kavâid, I: 230; Buhûtî, Keșşâfu'l-kına', 2: 498; Șirbînî, Muğni'l-muhtâc, 2: 43; Șemmâhî, Âmir b. AlI: Kitabü'l-îzâh (Muhammed b. Ömer el-Kasabî haşiyesi ile birlikte), 5. Baskı, Ammân 2005, 3: 340; Hâşim Ma'rûf, Nazariyyetü'l-akd, 431.

${ }^{120}$ Kâsânî, Bedâi'u's-sanâi', 7: 26; İbnu'l-Hümâm, Fethu'l-Kadîr, 6: 412; İbn Nüceym, el-Bahru'r-râik, 6: 143.

${ }^{121}$ İbn Nüceym, el-Bahru'r-râik, 6: 144; Zuhaylî, el-Fikhu'l-Mâlikiyyu'l-müyesser, 2: 397; Şâzelî, Nazariyyetu'ş-şart 223.

${ }^{122}$ Ahmed, el-Müsned, 2: 174; TirmizI: Büyu', 18; NesâI: 73.

123 İbnü'l-Münzir, el-İşrâf, 6: 41-42.
} 
yukarıda ele aldığımız fasit şartlı akitlerin neredeyse hepsi birden fazla akdin birleşmesi olarak görülebilir. ${ }^{124}$

Farklı ödeme planlarına göre birden çok fiyat seçeneği sunularak yapılan akit ile iki akdin karşılıklı yapılması şeklinde ortaya çıkan akitler diğer üç mezhebe göre de safkateyn kapsamında görülerek fasit sayılmıştır. ${ }^{125}$ Ancak Mâlikîlere göre birleştirilen iki akdin birbirine zıt olmaması durumunda akit de şart da sahihtir. Buna göre ileri sürülen şart, satım ve kira akitlerini bir arada yaptırmayı gerektiriyorsa akitle birlikte şart da geçerlidir. Ancak bunun dişında, tek akitte iki akdin birleşmesi sahih değildir. Bununla birlikte, şart koşanın vazgeçmesiyle akit geçerlik kazanır. ${ }^{126}$ Mezheplerin bu konudaki referansları "bir akit içinde iki akit" yapılmasını yasaklayan rivayetlerin yanı sıra Câbir (r.a) hadisi ile bir akitte satım ile selemin birleşmesini yasaklayan hadislerdir. ${ }^{127}$ Câ'ferîler'e göre bir akit içinde iki akdin birleştirilmesini yasaklayan rivayetler sahih değildir. Bu nedenle bir akit içinde başka bir akdin şart koşulması sahihtir.128

\subsubsection{Bir Akitte İki Şart Koşmak}

Hanbelîler hariç İslam hukukunda akitle birlikte öne sürülen şartın bir veya birden fazla olması arasında fark yoktur. Akitle birlikte ileri sürülen şartların her ikisi sahih, her ikisi fasit veya biri geçerli biri fasit olabilir. ${ }^{129}$

Hanbelîler'e göre ise akdin gereği veya akdin maslahatı olan şartlardan birkaç tanesinin tek akitte ileri sürülmesi sahihtir. Öne sürülen iki şarttan biri, bunlardan olursa akit yine geçerlidir. Ancak sahih dahi olsa bunların dışında tek akitte iki şart koşulması fasittir. Mesela, muhayyer olma, rehin, şahit ve kefil getirme şartlarıyla yapılan satım akdi, şartlarla birlikte sahihtir. ${ }^{130}$ Fakat hem öğüülmesi hem de eve teslim edilmesi şartıyla buğday satın almak bâtıldır. ${ }^{131}$

Buraya kadar gördüğümüz fasit şartların etkisi satım ve kira gibi bedelli akitlerde söz konusudur. Bu nedenle hibe, ödünç, kefâlet, havâle, vekâlet vb. akitler fasit bile olsa takyîdî şarttan etkilenmezler. Bu tür akitlerde şart hükümsüzdür. ${ }^{132}$ Hanefî fakîh İbn Âbidîn (ö.1252/1836), bunun sebebini şöyle açıklar: Fasit şartlar,

\footnotetext{
${ }^{124}$ Serahsî, el-Mebsût, 13: 16; Kâsânî, Bedâi'u's-sanâi', 7: 22; İbnu'l-Hümâm, Fethu'l-Kadîr, 6: 410

${ }^{125}$ Mâverdî, el-Hâvi'l-kebîr, V, 341; Şîrâzî, el-Mühezzeb, 2: 20-21; Cüveynî, Nihâyetü'l-matlab, V, 436; İbn Rüşd el-Cedd, el-Mukaddimât, 2: 66-67; Hirâkî, el-Muhtasar, 89; İbn Kudâme, el-Muğnî, 6: 324; Buhûtî, Keșşâfu'l-kına', 2: 498.

${ }^{126}$ Rüşd el-Cedd, el-Mukaddimât, 2: 66.

${ }^{127}$ Ahmed b. Hanbel, 2: 174,178; Ebû Davud, "Büyû'“, 25 ve “İcâre”, 70; Tirmizi “Büyû'“, 18-19.

128 Cemâlüddîn el-Hasen (el-Hüseyn) b. Yûsuf b. Alî İbnü'l-Mutahhar el-Hillî, Kavâidü'l-ahkâmi fî marifeti'l-helâl ve'l-harâm, thk. Müessesetü'n-neșri'l-İslâmî (Kum: Müessesetü'n-neşri'l-İslâmî, 1992), 2: 94 .

${ }^{129}$ Hirâkî, Ebû'l-Kâsım Necmuddin Cafer b. el-Hüseyn, el-Muhtasar (thk. Muhammed Züheyr eș-Șâviș), el-Mektebü'l-İslâmî, Dımeşk 2000, 89; Şemmâhî, Kitabü'l-îzâh, 3: 124-125; Ettafeyyiș, Muhammed b. Yûsuf b. Îsâ b. Sâlih el-Hafsî el-Adevî, Şerhu Kitâbi'n-Nîl ve şifâüll-'alîl, 2. Baskı, Mektebetü'l-İrşâd, Cidde 1983, 8: 148

${ }^{130}$ İbn Kudâme, el-Muğnî, 6: 334; Buhûtî, Keşşâfu'l-kına', 2: 497; Şâzelî, Nazariyyetu'ş-şart, 297-298.

${ }^{131}$ Buhûtî, Keșşâfu'l-kına', 2: 497.

${ }^{132}$ Senhûrî, Mesadiru'l-hak, 3: 129; Mahmasânî, Subhi Receb, en-Nazariyyetü'l-âmme lil-mûcebât ve'lukûd fiş-Şeriati'l-İslmaiyye (Beyrut: Dâru'l-İlm li'l-melâyîn, 1983), 2: 461; Karadâğ̂̂, Mebdeü'r-rizâ, 2 : 1170.
} 
karşılıksız bir fazlalığı gerektirir. Bunda ise faizin ya da en azından şüphesinin olduğu açıktır. Faiz ise, sadece karşılıklı borçlanmayı gerektiren (ivazlı) akitlerde söz konusudur. Bu nedenle fasit şartlar, ivazsız akitlerin hükmünü etkilemezler. ${ }^{133}$

\subsection{Hükümsüz (Bâtıl) Şartlar}

Akitle birlikte öne sürüldüklerinde kendileri geçersiz olup, akde etkisi olmayan şartlara batıl şart denir. İslam hukukçuları, bu şartları boş söz (lağv) olarak değerlendirirler. Doktrinde hangi şartların batıl olduğu konusundaki yaklaşımlar farklıdır. Genel kabulleri dikkate alıp gerekli görüldükçe farklı görüşlere de temas etmek suretiyle bu şartlar birkaç başlık altında ele alınabilir.

\subsubsection{Kimseye Faydası Olmayan Şartlar}

Satılan araca belirli bir yol, mekan ve zamanlarda binmeyi veya araçta belli marka yakıt tüketilmesini şart koşmak vb. böyledir. Nitekim bu şartların kimseye faydası yoktur. Fukahânın tamamına göre bu şartlar akdin sıhhatine zarar vermez, fakat kendileri batıldır. ${ }^{134}$

Hanefî mezhebinde bir grup fakîh, taraflara zararı dokunan şartların da hükümsüz olduğunu savunur. Buna göre, akit konusu malın satılmamasını, hibe edilmemesini, giyilmemesini, yenmemesini, kullanılmamasını vs. şart koşmak batıl, akit sahihtir. Ebû Yusuf'un (ö.189/798) bu konudaki yaklaşımı ise farklıdır. Ona göre bu şartlarla birlikte kurulan akit fasittir. ${ }^{135}$

Mâlikî mezhebinde, tarafların zararına yol açan şartlar akdin gereğini engellediği için akitle birlikte geçersizdir. Ancak şarttan vazgeçilirse akit sahih olur. İvazlı akitlerde durum böyleyken, diğer akitlerde (karz, rehin vb.) bu şartın akdi batıl kılacağı hususunda Mâliki mezhebinin fukahâsı hemfikirdirler. ${ }^{136}$

Akit konusuna menfaat sağlayan şartlar da akdin sıhhatini etkilemez. $\mathrm{Bu}$ durum mevzûun hayvan olması durumunda söz konusu olur. Mesela az yük yükleme, sıcak havalarda binmeme veya hiçbir zaman binmeme şartıyla binek hayvanı satmak böyledir. ${ }^{137}$

Bu şartların hükümsüz olması, şartı koşan tarafın daha sonra hak talebinde bulunamaması sebebiyledir. Hak araması yoksa bu şartlar fasit bile olsa taraflar arası anlaşmazlığa yol açmaz. Zira fasit şartın akdin sıhhatini ortadan kaldırmasının en temel sebebi çekişmeye yol açmasıdır. ${ }^{138}$

Mâliki fakih Şâtıbî’ye göre İslam hukukçularının konuyla ilgili yaklaşımları biri naklî diğeri aklî olmak üzere iki delile dayanır. Naklî delil; "Hz. Peygamber

\footnotetext{
133 İbn Âbidîn, Reddü'l-muhtâr, 7: 399.

134 Serahsî, el-Mebsût, 13: 13; Nevevî, el-Mecmu', 9: 447; Şirbînî, Muğni'l-muhtâc, 2: 46; İbn Âbidîn, Reddü'l-muhtâr, 7: 284; San'ânî, et-Tâcu'l-müzehheb, 2: 377; Şemmâhî, Kitabü'l-îzâh, 3: 132; Ettafeyyiș, Şerhu Kitâbi'n-nîl, 8: 149; Bilmen, Hukuk-ı İslamiyye ve Istılâhât-ı Fıkhiyye Kâmusu, 6: 24.

${ }^{135}$ Kâsânî, Bedâi'u's-sanâi', 7: 14; İbn Nüceym, el-Bahru'r-râik, 6: 142; Zuhaylî: el-Fıkhu'l-İslamî, 4: 481; Karadâğî, Mebdeü'r-rızâ, 2: 1173.

${ }^{136}$ Şâzelî, Nazariyyetu'şart, 233.

137 İbn Âbidîn, Reddü'l-muhtâr, 7: 285.

${ }^{138}$ Serahsî, el-Mebsût, 13: 15; Şâzelî, Nazariyyetu'ş-şart, 271; Düreynî, Buhûs, 2: 399.
} 
(s.a.s) şartlı satışı yasaklamıştır." 139 Bu rivayete göre şartlı alışverişlerin tamamı geçersiz olmalıdır. Hâlbuki yukarıda sahih şartlardan söz edilmişti. Ancak rivayette geçen şartlar, anlaşmazlığa yol açan veya akdin gereğini ortadan kaldıran şartlar şeklinde yorumlanmıştır. Aklen ise, sözleşmeler tarafların kendi mülkünde serbestçe tasarrufta bulunmasını gerektirir. $\mathrm{Bu}$ şartlar ise tasarrufu engellemektedir. ${ }^{140}$ Ayrıca sözlü tasarrufların gereği ve neticelerinde kanun koyucunun bir maksadı vardır. Bu sebeple, hiçbir gayesi olmayan şartların ileri sürülmesi abesle iştigaldir. 0 halde bu şartlar, dikkate alınmadığı gibi, akdin sıhhatine de zarar vermezler. ${ }^{141}$

\subsection{2. Üçüncü Şahıslara Fayda veya Zarar Sağlayan Şartlar}

Akitlerde üçüncü şahıslar lehine ileri sürülen şartların sıhhati konusunda yaklaşımlar farklıdır. Hanefî mezhebinde bu şartlar istisnasız hükümsüzdür. Onlara göre, bu şartın satıcı tarafından veya müşteri tarafından ileri sürülmesi arasında fark yoktur. Buna göre, üçüncü bir şahsın kullanması şartıyla araç satmak, başkasına ödünç vermek şartıyla alışveriş yapmak geçerli, şart batıldır. Hanefî fakîhlere göre bu şartlar, mülkte tasarruf hakkını engellemek suretiyle taraflardan birine zarar vermektedir. Dolayısıyla bu şartlarda başkalarının menfaatinin bulunması veya hayır amaçlı olmasına da itibar edilmez. ${ }^{142}$

Şâfiîler, bu şartlardan iyilik ve hayır manasına gelenleri istisna ederek akitle birlikte geçersiz olduğunu savunurlar. ${ }^{143}$ Hanbelî mezhebinde ise bu şartlar sahihtir. Onlara göre bu şartlar, ivazlı akitlerde olduğu gibi, diğer akit türlerinde de geçerlidir. Dolayısıyla mezhepte vakfedilen veya hibe edilen gayrimenkulün menfaatini belirli bir müddet istisna etmek sahihtir. ${ }^{144}$ Caferî mezhebinin görüşü de budur. ${ }^{145}$ Filanın bana borç vermesi veya semenin bir kısmını ödemesi gibi, üçüncü şahıslara zararı dokunan şartlar konusunda da aynı şeyleri söylemek mümkündür. ${ }^{146}$

\subsubsection{Hukukun Gerektirmediği Bir Şeyi Gerekli Kılan Şartlar}

Taraflardan birine mubah olan bir şeyin yapılmasını zorunlu hale getiren şartların hepsi bu kapsamda ele alınır. Akit, satın alınan malda mutlak manada tasarrufu gerektirir. $\mathrm{Bu}$ nedenle kumaşın elbise olarak kullanılması şartıyla satılması durumunda şarta itibar edilmez. Zira akit kumaşın giyilmesini gerektirmekle birlikte, müşterinin bunu yapması zorunlu değildir. 0 halde şart koşulsa bile, müşteri bunu yapıp yapmama konusunda serbesttir. Bu şartlarda mubah veya mendup olan bir şeyin akitle birlikte vacip kılınması söz konusudur.

\footnotetext{
${ }^{139}$ Taberânî, el-Evsat, 4: 335 (4361).

${ }^{140}$ Şâtıbî, el-Muvâfakât, 1: 273.

${ }^{141}$ Şâtıbî, el-Muvâfakât, 1: 276.

142 Burhânüddîn el-Buhârî, el-Muhitu'l-Burhânî, 6: 392; İbnu'l-Hümâm, Fethu'l-Kadîr, 6: 411; İbn Nüceym, el-Bahru'r-râik, 6: 142; İbn Âbidîn, Reddü'l-muhtâr, 7: 282-283.

${ }^{143}$ Nevevî, el-Mecmu', 9: 460; Şirbînî, Muğni'l-muhtâc, 2: 42.

${ }^{144}$ Buhûtî, Keșşâfu'l-kına', 2: 497; İbn Teymiyye, el-Fetâvâ, 4: 81; İbn Receb, el-Kavâid, I: 231-233.

${ }^{145}$ Hillî, Kavâidül'-ahkâm fî ma'rifeti'l-helâl ve'l-harâm, 2: 89-90.

146 İbn Kudâme, el-Muğnî, 6: 330; Şâzelî, Nazariyyetü'ş-şart, 208.
} 
Bu nedenle İslam hukukçuları bu şartları batıl olarak değerlendirmişlerdir. Çünkü kanun koyucudan başka hiç kimse mubahı vacip kılma yetkisine sahip değildir. ${ }^{147}$

\subsubsection{Akitle Elde Edilen Haklardan Birini İptal Eden Şartlar}

Sahih olarak vücut bulan akdin, taraflara ve üçüncü şahıslara sağladığı birtakım haklar vardır. Ön alım (suf'a) hakkı, muhayyerlik hakkı, akit konusunda ve bedelde tasarrufta bulunma hakkı vb. akitten doğan haklardır.

İslam hukuk bilginlerinin çoğu, bu şartların hükümsüz, akdin geçerli olduğunu savunurlar. Mesela şuf'a hakkına sahip olanlardan birinin bu hakkını istemesi durumunda, alışverișten vazgeçilmesi şartıyla gayrimenkul satmak batıl, akit sahihtir. ${ }^{148}$ Bu konuda dayanak İbn Ömer (r.a) ile Zeyd b. Sabit (r.a) arasında geçen ve ayıp muhayyerliğinin şartla düşürüldüğü bir alışverişi konu edinen rivayettir. ${ }^{149}$ Dolayısıyla kusurdan sorumlu olmamayı şart koşmak diğer tarafın muhayyerlik hakkını ortadan kaldırmaz. Çünkü ayıp muhayyerliği hakkı akitten sonra elde edilir. Akitten önce şartla düşürülmesi, olmayan bir hakkın iptali anlamına gelir ki bu hukuki açıdan geçerli değildir. ${ }^{150}$

Bâtıl (lağv) şartların akdin hükmünü etkilememesinin temel sebebi, taraflar arası çekişmeye (nizâ) yol açma ihtimalinin bulunmamasıdır. Çünkü bu şartlar genelde taraflara fazladan bir menfaat sağlayacak mahiyette ve nitelikte değildir. Böyle olunca şartı koşanın hak arayışı içine girmesi neticesinde tarafların anlaşmazlığa düşmesi söz konusu olmamaktadır. ${ }^{151}$ Nitekim Akdin fesadına yol açan unsurların (garar, cehâlet, zarar, fasit şart vb.) taraflar arası anlaşmazlığa götürmekle kayıtlı olması bilinen bir husustur. ${ }^{152}$

\section{Sonuç}

Akitlere etkisi bakımından takyîdî şartların hükmünü ele aldığımız bu çalışmada ulaşılan neticeleri kendi kanaatlerimizi de ekleyerek şu şekilde izah etmek mümkündür:

\footnotetext{
${ }^{147}$ Nevevî, el-Mecmu', 9: 447; Şirbînî, Muğni'l-muhtâc, 2: 46; İbn Kudâme, el-Muğnî, 6: 325; İbn Nüceym, el-Bahru'r-râik, 6: 142; Buhûtî, Keșșâfu'l-kına', 2: 499.

${ }^{148}$ Buhûtî, Keșşâfu'l-kına', 2: 501; San'ânî, et-Tâcu'l-müzehheb, 2: 371; Hâșim Ma'rûf, Nazariyyetü'l-akd, 436; Zuhaylî, el-Fikhu'l-Mâlikiyyu'l-müyesser, 2: 396; Şâzelî, Nazariyyetu'ş-şart, 401.

${ }^{149}$ Muvatta, 2: 613. "İbn Ömer (r.a) Zeyd b. Sâbit'e (r.a) ayıp ve kusurdan sorumlu olmaması şartıyla bir köle satar. Köle daha sonra ayıplı çıkınca Zeyd (r.a) geri vermek ister ama İbn Ömer bunu kabul etmez. Dava Halife Osman b. Affan'a (r.a) tașınınca, İbn Ömer'e (r.a): "Bu ayıptan haberdar olmadığına dair yemin eder misin" dedi. $O$ da hayır diyince köleyi kendisine iade etti." Beyhakî, bu hadisin Müsned'de geçtiğini zikretmiştir. Ancak Keşşâfu'l-kına'yı Suudi Arabistan Adalet Bakanlığı tarafından tahkik eden komisyona göre, bu hadis Müsned'te değil de Abdullah b. Ahmed'in mesailinde geçmektedir. (Detaylı bilgi için bk. Keşşâfu'l-kına'nın adı geçen komisyon tahkikine 7: 406.)

${ }^{150}$ Buhûtî, Keşşâfu'l-kına', 2: 501.

${ }^{151}$ Senhûrî, Mesâdiru'l-hak, 3: 132.

152 Kâsânî, Bedâi'u's-sanâi', 7: 21; Merğ̂̂nânî, el-Hidâye, 3: 50; Apaydın, İslam Hukukunda Hukuki İşlemlerin Hükümsüzlüğü, 133; Geniş bilgi için bk. Mahmut Samar, İslam Hukukunda Akitlerin Birleștirilmesi (Safkateyn) yasağı ve Günümüz Finans Uygulamalarına Etkisi (Doktora Tezi, Necmettin Erbakan Üniversitesi, 2018), 210 vd.
} 
Takyîdî şartlar, akitlerde fazladan bir borçlanmayı gerekli kılmak için akitle birlikte ileri sürülen ve günümüzde muhtevayı düzenleme hürriyetinin bir aracı olarak tartışılmaktadır. Klasik fıkıh kaynaklarında bu hürriyetin sınırlarını ifade etmek üzere İslam hukukçuları, bu şartları sahih, fasit ve batıl olmak üzere üçe ayırmıșlardır. Buna göre muhtevayı düzenleme serbestisi sahih șartların alanıyla sınırlıdır. Bu açıdan İslam hukuk ekolleri dardan genişe doğru; Zâhirîler, Hanefîler, Şâfiîler, Mâlikîler ve Hanbelîler şeklinde sıralanabilir.

Teorik açıdan bu sıralama her ne kadar doğru olsa da pratikte kayda değer bir farklılığın olmadığı kanaatindeyiz. Nitekim uygulamada Zâhirîler istisna edilecek olursa fıkıh mezhepleri birbirlerine çok yaklaşmışlardır. Nitekim bu alanda kural olarak hürriyet prensibini benimsemediği halde Hanefî mezhebi örfe geniş yer vermek suretiyle uygulamada diğer mezheplerle neredeyse aynı noktaya gelmiştir.

Diğer taraftan günümüzde taraflar arası sözleşmelerde belirleyici esas unsur çoğu zaman tarafların ileri sürdükleri şartlardır. Belirli şartların öne sürülmediği bir sözleşmenin neredeyse mümkün olmadığı gerçeği dikkate alındığında akitlerde şart koșma hürriyetinin geniş tutulmasının daha isabetli olduğu söylenebilir. Ayrıca klasik fıkıh kaynaklarında yer alan örneklerden anlaşıldığı üzere akitlerin şart ve hükümleri o dönemin teâmülleri dikkate alınarak tespit edilmiştir. Aynı şekilde örneklerden anlaşıldığı üzere konuyla ilgili tartışmaların o dönemin üretim imkân ve araçlarından yola çıkılarak bir meslek erbâbının ürettiği eşya boyutunda veya küçük çaplı ticârî akitler ile ilgili olduğu görülür. $\mathrm{Bu}$ nedenle günümüzde konusu devasa projeler olan akitlerle birlikte bir takım şartların koşulması, ihtiyaçların giderilmesi ve olası mağduriyetlerin önlenmesi adına zorunlu hale gelmiştir. $\mathrm{Bu}$ itibarla naslara açıç̧a muhalefet etmediği, akdin gereğine de aykırı olmadığı sürece, akitle birlikte tarafların ihtiyaç duyduğu şartları öne sürme serbestisinin geniş tutulması ve anlaşmazlık halinde örfün hakemliğine başvurulmasının en uygun yaklaşım olduğu söylenebilir.

\section{Kaynakça}

Ahmed b. Hanbel, el-Müsned. Thk. Ahmed Muhammed Şâkîr. Kahire: Dâru'l-Hadîs, 1997.

Akıntürk, Turgut, "Şart ve Mükellefiyet Kavramları Üzerine Bir İnceleme”, Ankara Üniversitesi Hukuk Fakültesi Dergisi 27/3 (1970): 219-247.

Apaydın, Yunus, İslam Hukukunda Hukuki İşlemlerin Hükümsüzlüğü. Doktora Tezi. Ankara Üniversitesi, 1989.

Aynî, Ebû Muhammed Mahmud b. Ahmed, el-Binâye fí șerhi'l-Hidâye. Thk. Eymen Salih Şâban. Beyrut: Dâru'l-Kütübi'l-ilmiyye, 2000.

Bardakoğlu, Ali. "İslâm Hukukunda Akit Hürriyeti ve Akdî Şartlar Açısından Bu Hürriyetin Sınırı". Erciyes Üniversitesi İlahiyat Fakültesi Dergisi 1 (1983): 8-29.

Bilmen, Ömer Nasuhi. Hukuki İslâmiyye ve Istalahat-ı Fıkhîyye Kâmusu, İstanbul: Sarmaşık Yayınları, 1970.

Boynukalın, Mehmet. "Şart”. Türkiye Diyanet Vakfi İslam Ansiklopedisi. 38: 364-365. İstanbul: TDV Yayınları, 2010.

Buhârî, Ebû Abdillah Muhammed b. İsmail. el-Câmiu's-sahîh. Dımeşk: Dâr İbn Kesîr, 2002.

Buhûtî, Mansûr b. Yunus b. İdris. Keşşâfu'l-kına' 'an metni'l-İkna'. Thk. Muhammed Emîn ez-Zinnâvî. Beyrut: Âlemü'l-kütüb, 1997.

Burhânü’ş-Şerîa, Burhânüddîn Mahmud b. Ahmed b. Abdulazîz el-Buhârî el-Mergînânî. el-Muhîtu'lBurhânî fi'l fikhî̀n-Nu'mânî. Thk. Abdulkerîm Sâmi el-Cündî. Beyrut: Dâru'l-Kütübi'l-İlmiyye, 2004. 
Cüveynî, Ebû'l-Meâlî Abdülmelik b. Abdillah. Kitâbu't-Telhîs fî Usûli'l-Fıkh. Thk. Abdullah Cevlim enNiybâli-Beşîr Ahmed el-Ömerî. Beyrut: Dâru'l-Beşâiri'l-İslâmiyye, 1996.

Çeker, Orhan. Fıkıh Dersleri. Konya: Ensar yayıncılık, 2011.

Çeker, Orhan. İslam Hukukunda Akidler. Konya: Tekin kitabevi, 2010.

Çiğdem, Recep. Mukayeseli Borçlar Hukuku. İstanbul: Rağbet Yayınları, 2012.

Dâmâd, Abdurrahman b. Muhammed b. Süleyman. Mecma'u'l-enhur fî șerhi Mülteka'l-ebhur. Thk. Muhammed Ahmed el-Muhtâr. Beyrut: Dârü'l-Kütübi'l-ilmiyye, 2016.

Debûsî, Ebû Zeyd Ubeydullah Ömer b. İsa. Takvîmü'l-edille fi usûli'l-fikh. Thk. Halil el-Meys. Beyrut: Dârü'l-Kütübi'l-ilmiyye, 2001.

Düreynî, Muhammed Fethi. Buhûs mukârene fi'l-Fıkhi'l-İslamî. Beyrut: Müessesetü'r-Risâle, 2008.

Ebû Dâvûd, Süleyman b. Eş’as es-Sicistâni. es-Sünen. Thk. Şuayb Arnâut ve Muhammed Kâmil. Dımeşk: Dâru'r-Risâleti'l-'alemiyye, 2009.

Erdoğan, Mehmet. Fıkıh ve Hukuk Terimleri Sözlüğü. İstanbul: Ensar Yayınları, 2010.

Eren, Fikret. Borçlar Hukuku Genel Hükümler. Ankara: Beta yayınları, 1987.

Ettafeyyiş, Muhammed b. Yûsuf b. Îsâ b. Sâlih el-Hafsî el-Adevî. Şerhu Kitâbi'n-Nîl ve şifâü'l-'alîl. Cidde: Mektebetü'l-İ́şâd, 1983.

Feyyûmî, Ahmed b. Muhammed b. Ali. el-Misbâhu'l-münîr fi garibi'ş-Şerhi'l-kebîr. Kahire: Dâru'l-hadîs, 2003.

Firuzâbâdî, Mecduddîn Muhammed b. Yakub. el-Kâmusu'l-muhît. Thk. Muhammed Naim el-'Arğûsî danıșmanlığında yayınevi) Beyrut: Müessesetü'r-Risâle, 2005.

Güney, Necmeddin. Satım Akdî Özelinde Íslam Borçlar Hukukunda Garar. Doktora Tezi. Necmettin Erbakan Üniversitesi, 2013.

Haçkalı, Abdurrahman. Íslam Hukukunda Satım Akdiyle İlgili Şartlar. Yüksek Lisans Tezi. Ondokuz Mayıs Üniversitesi, 1995.

Hâșim Ma'rûf, el-Huseynî. Nazariyyetü'l-akd fi'l-fikhî'l-Câferî. Beyrut: Dâru't-te'ârif, 1996.

Hillî, Cemâlüddîn el-Hasen (el-Hüseyn) b. Yûsuf b. Alî İbnü'l-Mutahhar. Kavâidü'l-ahkâmi fî ma'rifeti'lhelâl ve'l-harâm. Thk. Müessesetü'n-neșri'l-İslâmî. Kum: Müessesetü'n-neșri'l-İslâmî, 1992.

Hirâkî, Ebû'l-Kâsım Necmuddin Cafer b. El-Hüseyn. el-Muhtasar. Thk. Muhammed Züheyr eş-Şâviş. Dımeșk: el-Mektebü'l-İslâmî, 2000.

İbn Âbidîn, Muhammed Emin b. Ömer b. Abdilaziz ed-Dımașkî. Reddü'l-muhtâr 'ale'd-Dürri'l-muhtâr şerhu Tenviri'l-ebsâr. Thk. Adil Ahmed Abdülmevcûd - Ali Muhammed Muavviz. Riyad: Dâr 'Alemi'l-kütüb, 2003.

İbn Hazm, Ebu Muhammed Ali b. Ahmet b. Said. el-Muhallâ bi'l-âsâr. Thk. Abdülğaffâr Süleyman elBindârî. 3. Baskı. Beyrut: Dâru'l-Kütübi'l-İlmiyye 1934.

İbn Kudâme, Ebu Muhammed Ali b. Ahmed b. Muhammed. el-Muğnî. Thk. Abdullah b. Abdülmuhsin etTurkî-Abdülfettah Muhammed. Riyad: Dâr 'Âlemi'l-kütüb, 1997.

İbn Manzûr, Muhammed b. Mükerrem. Lisânu'l-'Arab. Beyrut: Dâr Sâdır, 1993.

İbn Nüceym, Zeynulâbidîn b. İbrahim, b. Muhammed. el-Bahru'r-râik şerhu Kenzü'd-dekâik. Thk. Zekeriya 'Umeyrât. Beyrut: Dâru'l-Kütübi'l-ilmiyye, 1997.

İbn Nüceym, Zeynulâbidîn b. İbrahim, b. Muhammed. el-Eşbah ve'n-nezâir 'alâ mezhebi Ebî Hanîfe enNu'mân. Thk. Zekeriya Umeyrât. Beyrut: Dâru'l-kütübi’l-İlmiyye, 2010.

İbn Receb el-Hanbelî, Ebü'l-Ferec Zeynüddîn Abdurrahmân b. Ahmed b. Abdirrahmân Receb el-Bağdâdî ed-Dımașkî. el-Kavâid (Takrîrü'l-ksavâ'id ve tahrîrül-fevâ'id). Beyrut: Dâru'l-Kütübi'l-ilmiyye, ty..

İbn Rüşd el-Cedd, Ebü'l-Velîd Muhammed b. Ahmed. el-Beyân ve't-tahsîl ve'ş-șerh ve't-tevcîh ve't-ta'lîl li meseili'l-müstahrece. Thk. Muhammed Haccî vdğ. 2. Baskı, Beyrut: Dâru'l-Garbi'l-İslâmî, 1988.

İbn Rüșd el-Cedd, Ebü'l-Velîd Muhammed b. Ahmed. el-Mukaddimâtü'l-mümehhidât. Thk. Muhammed Haccî. Beyrut: Dâru'l-Ğarbi'l-İslâmî, 1998.

İbn Rüşd el-Hafîd, Ebu'l-Velîd Muhammed b. Ahmed. Bidayetü'l-müctehid ve nihâyetü'l-muktesıd. Thk. Ferîd Abdülaziz el-Cündî. Kahire: Dârü'l-Hadîs, 2004.

İbn Teymiye, Takiyuddin Ahmed b. Abdulhalim. el-Fetâve'l-Kübrâ. Thk. Muhammed, Abdulkadir Atâ Mustafa, Abdulkadir Atâ. Beyrut: Dâru'l-Kütübi'l-ilmiyye, 1987.

İbn Teymiye, Takiyuddin Ahmed b. Abdulhalim. Mecmûatü'l-fetâvâ. Thk. Âmir el-Cezzar - Enver el-Bâz. Riyad: Mecma'u'l-Melik Fehd li't-tıbâa, 2005.

İbnü'l-Hümâm, Kemâlüddîn Muhammed b. Abdilvâhid b. Abdilhamîd es-Sivâsî el-İskenderî. Fethu'lKadîr. Thk. Abdürrezzâk Galib el-Mehdî. Beyrut: Dâru'l-Kütübi'l-İlmiyye, 2003.

Karadâğî, Ali Muhyiddîn. Mebde'ü'r-rıâ fi'l-'ukûd: Dirâse mukârene fi'l-fıkhî'l-İslamî. Beyrut: Dâru'lBeşâir, 1985.

Karâfî, Ebü'l-Abbâs Şihâbüddîn Ahmed b. İdrîs b. Abdirrahmân el-Misrî. Envârü'l-burûk, fî envâ'i'l-furûk; el-Furûk. Thk. Ömer Hasan el-Kayyâm. Beyrut: Müessesetü'r-risâle, 2014.

Karaman, Hayreddin. Ana Hatlarıyla İslam Hukuku. İstanbul: Ensar neșriyat, 2014. 
Kâsâni, Ebi Bekr Alâuddîn b. Mes'ud. Bedai'u's-sanâi' fi tertibi'ş- șerâii' Thk. Ali Muhammed Muavviz-Âdil Ahmed Abdülmevcûd. 2. Baskl, Beyrut: Dâru'l-Kütübi'l-İlmiyye, 2003.

Köse, Saffet. İslam Hukukuna Giriş. İstanbul: Hikmetevi Yayınevi, 2017.

Kummî, İbn Bâbeveyh, Ebû Ca'fer Muhammed b. Ali b. Hüseyn. Kitâb Men la yahduruhü'l-fakîh. Thk. Hüseyin el-A'lemî. Beyrut: y.y., 1986.

Mahmasânî, Subhi Receb. en-Nazariyyetü'l-'âmme lil-mûcebât ve'l-'ukûd fiş-şeriati'l-İslmaiyye. Beyrut: Dâru'l-İlm li'l-melâyîn, 1983.

Mâlik, Ebû Abdillâh Mâlik b. Enes b. Mâlik b. Ebî Âmir el-Asbahî el-Yemenî. el-Muvatta (Şeybânî rivayeti): Leknevî şerhiyle birlikte. Thk. Takiyüddîn en-Nedvî. Dımeșk: Dâru'l-Kalem, 2011.

Mâverdi, Ebu'l-Hasan Ali b. Muhammed b. Habîb. el-Hâvi'l-kebîr fí fikhî mezhebi'l-İmâmi'ş-Şâfiî; şerhu Muhtasari'l-Müzenî. Thk. Ali Muhammed Muavviz - Adil Ahmed Abdülmevcûd. Beyrut: Dâru'lKütübi'l-İlmiyye, 1994.

Merğînânî, Burhanuddîn Ebû'l-Hasen Ali b. Ebû Bekir. el-Hidaye fî şerhi Bidayeti'l-mübtedî. Thk. Talal Yusuf. Beyrut: Dâr İhyai't-türâsi'l-'Arabî, 2004.

Mevsılî, Ebü'l-Fazl Mecdüddin Abdullah b. Mahmûd b. Mevdûd. el-ihtiyar li-ta'lîli'l-Muhtar. Thk. Muhammed Adnan Derviș. Beyrut: Dâru'l-Kütübi'l-ilmiyye, 1997.

Meydânî, Abdulğanî el-Ğanîmî. el-Lubab fi șerhi'l-Kitab. Thk. Abdurrezzak el-Mehdî. Beyrut: Dâru'lkitâbi'l'Arabî, 2010.

Müzenî, Ebu İbrahim İsmail b. Yahya b. İsmail. Muhtasaru'l-Müzenî fi fürûi'ş-Şâfiiyyeti. Thk. Muhammed Abdülkadir Şahin. Beyrut: Dâru'l-Kütübi'l-İlmiyye, 1998.

Nesâi, Ebu Abdurrahman Ahmed b. Şu'ayb. el-Müctebâ mine's-Sünen; es-Süneni's-suğrâ. Thk. Abdülfettah Ebû Ğudde. Halep: Mektebetü'l-metbûâti'l-İ̇lâmiyye, 1986.

Nevevî, Ebû Zekeriyya Yahya b. Şerif b. Mürî. el-Mecmû' şerhu'l-Mühezzeb. Beyrut: Dâru'l-fikr, ty..

Özdirek, Recep, İslam Hukukunda Akdin Sinırları, İstanbul: Yedirenk yayınları, 2010.

Remlî, Ebû Abdillâh Şemsüddîn Muhammed b. Ahmed b. Ahmed b. Hamza er-Remlî el-Menûfî el-Ensârî el-Mısrî. Nihâyetü'l-muhtâc ilâ șerhi'l-Minhâc. 3. Baskı. Beyrut: Dâru'l-Kütübi'l-ilmiyye, 2003.

Sahnûn, Ebû Saîd Abdisselam b. Saîd et-Tenûhî. el-Müdevvenetü'l-kübrâ. Beyrut: Dâru'l-Kütübi'l-İlmiyye, 1994.

Samar, Mahmut. İslam Hukukunda Akitlerin Birleștirilmesi (Safkateyn) yasağı ve Günümüz Finans Uygulamalarına Etkisi. Doktora Tezi. Necmettin Erbakan Üniversitesi, 2018.

San'ânî, Ahmed b. Kasım el-İnsî el-Yemenî. et-Tâcu'l-müzehheb li ahkâmi'il-mezheb, şerhu metni'l-Ezhâr fi Fıkhî'l-eimmeti'l-ethâr. San'â: Dâru'l-Hikmeti'l-Yemâniyye, 1993.

Senhûrî, Abdurrezzâk Ahmed. Mesâdiru'l-hak fi'l-fikhî'l-İ́slamî. Beyrut: Menşûrâtü'l-Halebî, 1998.

Serahsî, Șemsu'l-eimme Muhammed b. Ahmed b. Sehl. el-Mebsût. Beyrut: Dâru'l-Ma'rife, 1989.

Suyûtî, Celâlüddîn Abdurrahman. el-Eşbâh ven-nazâir fi kavâid ve fürû' fikhî’ş-Şâfiiyye, Riyad y.y., 1997.

Şabân, Zekiyuddîn. İslam Hukuk İlminin Esasları. Trc. İbrahim Kâfi Dönmez. Ankara: TDV yayınları, 2010.

Şâtıbî, Ebû İshak İbrahim b. Musa. el-Muvâfakât. Trc. Mehmet Erdoğan. İstanbul: İz yayıncllık, 2010.

Şâzelî, Hasan Ali. Nazariyyetu'ş-şart fi'l-Flkhi'l-İslamî: Dirâse mukârene beyne'l-fikhi'l-islâmî ve'l-Kânûn. Kahire: y.y., ty..

Şemmâhî, Âmir b. Ali. Kitabü'l-îzâh (Muhammed b. Ömer el-Kasabî haşiyesi ile birlikte). 5. Baskı. Ammân: y.y., 2005.

Şeybânî, Muhammed b. Hasan. el-Asl (el-Mebsût). Thk. Mehmet Boynukalın. Beyrut: Dâr İbn Hazm, 2012.

Şîrâzî, Ebu İshak İbrahim b. Ali b. Yusuf. el-Mühezzeb fî fikhîl'-imam eş-Şâfiî. Thk. Zekeriyya Umeyrât. Beyrut: Dâru'l-Kütübi'l-ilmiyye, 1995.

Şirbînî, Muhammed b. Hatîb. Muğni'l-muhtâc ila ma'rifeti me'âni'l-Minhâc. Thk. Muhammed Halil 'Aytânî. Beyrut: Dâru'l-Ma'rife, 2014.

Taberânî, Ebû'l-Kasım Süleyman b. Ahmed b. Eyyub b. Mutayr el-Lahmî. el-Mu'cemü'l-evsat. Thk. Tarık b. İvazullah b. Muhammed - Abdülmuhsin b. İbrahim el-Huseynî. Kahire: Dâru'l-Harameyn, ty..

Tirmizî, Ebu İsa Muhammed b. İsa b. Serve. el-Câmi'u'l-kebîr; Sünenüt-Tirmizî. Thk. Beşşâr Avvâd Ma'rûf. Beyrut: Dâru'l-Ğarbi'l-İ̀lâmî, 1998.

Zerkâ, Mustafa Ahmed. el-Medhalü'l-fikhiyyu'l-'âm. Dimeșk: Dâru'l-Kalem, 1998.

Zeydân, Abdülkerîm. el-Medhal lidirâseti'ş-Şeriati'l-İslamiyye. Beyrut: Müessesetü'r-Risâle, 2002.

Zeydân, Abdülkerîm. el-Vecîz fị șerhi'l-kav âidi'l-fikhîyye. Beyrut: Müessesetü'r-Risâle, 2014.

Zeydân, Abdülkerim. el-Vecîz fí usuli'l-fikh. Beyrut: Müessesetü'r-Risâle, 2012.

Zuhayli, Vehbe. el-Flkhu'l-İslamî ve edilletüh. Dımeșk: Dâru'l-Fikr, 1989.

Zuhayli, Vehbe. el-Fikhu'l-Mâlikiyyü'l-müyesser. Dımaşk: Dâru'l-Kelimi't-Tayyib, 2010. 